OPEN ACCESS

Edited by:

Abraham J. Escobar-Gutiérrez, Institut National de la Recherche Agronomique (INRA), France

Reviewed by:

Dominique Job,

Centre National de la Recherche

Scientifique (CNRS), France

Łukasz Wojtyla,

Adam Mickiewicz University in

Poznan, Poland

*Correspondence:

Lixiao Nie

nielixiao@mail.hzau.edu.cn

Specialty section:

This article was submitted to

Crop and Product Physiology,

a section of the journal

Frontiers in Plant Science

Received: 13 November 2017

Accepted: 30 January 2018

Published: 13 February 2018

Citation:

Wang W, He A, Peng S, Huang J, Cui $K$ and Nie $L$ (2018) The Effect of

Storage Condition and Duration on the Deterioration of Primed Rice Seeds. Front. Plant Sci. 9:172 doi: 10.3389/fpls.2018.00172

\section{The Effect of Storage Condition and Duration on the Deterioration of Primed Rice Seeds}

\author{
Weiqin Wang ${ }^{1}$, Aibin $\mathrm{He}^{1}$, Shaobing Peng ${ }^{1}$, Jianliang Huang ${ }^{1}$, Kehui Cui ${ }^{1}$ and Lixiao Nie ${ }^{1,2 \star}$ \\ ${ }^{1}$ MOA Key Laboratory of Crop Ecophysiology and Farming System in the Middle Reaches of the Yangtze River, College of \\ Plant Science and Technology, Huazhong Agricultural University, Wuhan, China, ${ }^{2}$ Hubei Collaborative Innovation Center for \\ Grain Industry, Yangtze University, Jingzhou, China
}

Seed priming is a successful practice to improve crop establishment under adverse environment. However, reduced longevity of primed rice (Oryza sativa L.) seeds during storage limited the adoption of this technique. Present study investigated the effect of temperature, relative air humidity $(\mathrm{RH})$ and oxygen on the longevity of primed rice seeds in a range of 60 days storage. In addition, the biochemical and morphological mechanisms associated with deterioration of primed seeds during storage were explored. Three types of priming treated rice seeds and one non-primed control were stored under (1) low temperature-vacuum (LT-V), (2) room temperature-vacuum (RT-V), (3) room temperature-aerobic-low $\mathrm{RH}(\mathrm{RT}-\mathrm{A}-\mathrm{LH})$ and (4) room temperature-aerobic- high $\mathrm{RH}$ $(\mathrm{RT}-\mathrm{A}-\mathrm{HH})$ for $0,15,30,45$, and 60 days. The results showed that storage of seeds under different conditions for 15-60 days did not influence the longevity of non-primed rice seeds. Meanwhile, the viability of primed rice seeds did not reduce when stored under LT-V, RT-V, and RT-A-LH, but was significantly reduced under RT-A-HH. Under vacuum condition, the increases of storage temperature $\left(30^{\circ} \mathrm{C}\right)$ did not reduce the longevity of primed seeds. Likewise, the oxygen did not influence the longevity of primed rice seeds stored under low $\mathrm{RH}$. Nevertheless, increase of $\mathrm{RH}$ significantly reduced the viability of primed seeds stored for 15-60 days. Reduced starch metabolism, the consumption of starch reserves in rice endosperms, the accumulation of malondialdehyde and the decreases of antioxidant enzyme activities might be associated with the deterioration of primed rice seeds during storage. In conclusion, storage of primed seeds under high $\mathrm{RH}$ condition beyond 15 days is deteriorative for germination and growth of rice. The primed rice seeds are recommended to store at vacuum or low $\mathrm{RH}$ or low temperature condition to ensure good crop establishment.

Keywords: seed priming, seed longevity, storage condition, starch metabolism, lipid peroxidation, antioxidant enzyme

\section{INTRODUCTION}

Seed priming refers to the seed treatment that hydrating the seeds before sowing to activate several metabolic events, but radicle protrusion does not occur (Heydecker and Coolbear, 1977). Several reports have been proved that seed priming was effective in promoting seed germination, enhancing seedling growth of rice (Oryza sativa L.) under chilling (Hussain et al., 2016a; Wang et al., 2016), 
drought (Zheng et al., 2016), and waterlogging stresses (Hussain et al., 2016b). Nevertheless, viability losses of primed seeds during storage is a major limiting factor to wide adoption of seed priming technique.

It has been suggested that the seed longevity is influenced by several factors such as temperature, oxygen, relative air humidity and seed moisture content (Rajjou and Debeaujon, 2008). Our previous research found that the germination percentage and growth attributes of primed rice seedlings were significantly reduced when stored at 25?, while no significant decrease was found when primed seeds were store at $-4^{\circ} \mathrm{C}$ (Hussain et al., 2015). However, the research of Hussain et al. (2015) ignored the influence of oxygen concentration and the relative air humidity $(\mathrm{RH})$ during storage, which are known to greatly impact the seed longevity.

Oxygen has been suggested to be an important factor to regulate series of physiological processes caused by respiration, which was associated with seed deterioration. It has been reported that $\mathrm{O}_{2}$ accelerated the accumulation of super oxide and lead to $\mathrm{O}_{2}$ injury to seeds during storage (Hendry, 1993). Ellis et al. (2008) reported that oxygen increased the respiration rate and accelerated the seed deterioration at high temperature. Wilson and McDonald (1986) observed that high oxygen concentration accelerated seed deterioration by depleting protective antioxidants. Likewise, $\mathrm{RH}$ is also considered as a major factor that control the longevity of the seed in processing and storage (Justice and Bass, 1978). High RH along with

TABLE 1 | Mean temperature, mean relative humidity, and oxygen availability of four storage conditions and four storage durations.

\begin{tabular}{|c|c|c|c|c|}
\hline $\begin{array}{l}\text { Storage } \\
\text { condition }\end{array}$ & $\begin{array}{c}\text { Storage } \\
\text { duration } \\
\text { (days) }\end{array}$ & $\begin{array}{c}\text { Temperature } \\
\left({ }^{\circ} \mathrm{C}\right)\end{array}$ & $\begin{array}{c}\text { Relative } \\
\text { humidity } \\
(\%)\end{array}$ & $\begin{array}{l}\text { Aerobic } \\
\text { or } \\
\text { vacuum }\end{array}$ \\
\hline \multirow[t]{4}{*}{ LT-V } & 1 & -4.00 & 0 & Vacuum \\
\hline & 30 & & & \\
\hline & 45 & & & \\
\hline & 60 & & & \\
\hline \multirow[t]{4}{*}{ RT-V } & 15 & 29.79 & 0 & Vacuum \\
\hline & 30 & 30.64 & & \\
\hline & 45 & 31.12 & & \\
\hline & 60 & 30.81 & & \\
\hline \multirow[t]{4}{*}{ RT-A-LH } & 15 & 29.79 & 26.00 & Aerobic \\
\hline & 30 & 30.64 & 24.56 & \\
\hline & 45 & 31.12 & 23.73 & \\
\hline & 60 & 30.81 & 22.81 & \\
\hline \multirow[t]{4}{*}{ RT-A-HH } & 15 & 29.79 & 56.96 & Aerobic \\
\hline & 30 & 30.64 & 62.87 & \\
\hline & 45 & 31.12 & 64.62 & \\
\hline & 60 & 30.81 & 66.68 & \\
\hline
\end{tabular}

$L T-V$, the primed and non-primed seeds were stored under vacuum, low temperature condition; RT-V, the primed and non-primed seeds were stored under vacuum, room temperature condition; RT-A-LH, the primed and non-primed seeds were stored under room temperature, aerobic and low relative humidity condition; RT-A-HH, the primed and non-primed seeds were stored under room temperature, aerobic and high relative humidity condition. high temperature quickly accelerate the deterioration of the seed and thereby cause aging. Therefore, exposure of seed to high temperature and high moisture condition have been wildly used in the controlled deterioration (CD) test by many researchers. Low $\mathrm{RH}$ largely reduced the seed deterioration even with high storage temperature (Suma et al., 2013), suggesting that $\mathrm{RH}$ might be more important than the storage temperature in determine the seed longevity. Besides, $\mathrm{RH}$ has been reported to be interacts with oxygen in determining the seeds longevity during storage. Schwember and Bradford (2011) reported that the presence of $\mathrm{O}_{2}$ severely decreased the longevity of primed seeds under low $\mathrm{RH}$, while such phenomena was not observed under high RH. Although the influence of temperature, $\mathrm{RH}$ and oxygen concentration on the longevity of normal seeds during storage have been widely studied for several years. The effect of these environmental factors on the longevity of primed rice seeds has rarely been studied.

Starch metabolism is one of the major metabolic event and driving force during rice seed germination. It has been widely reported that the rice seeds germination was significantly correlated with the starch metabolism in rice seeds. Several researches have observed significant reduction of $\alpha$-amylase activity and total soluble sugar contents in aged seeds (Garcia et al., 2006; Goyoagaa et al., 2011), suggesting that the restriction of starch metabolism might be responsible for the reduced seed germination after storage. For primed seeds, Hussain et al. (2015) observed significant decreases in starch metabolism of primed seeds stored under $25^{\circ} \mathrm{C}$, while such decreases were not observed when primed seeds were stored under $-4^{\circ} \mathrm{C}$. In spite of starch metabolism, the consumption of food reserves in rice endosperm might also be responsible for the viability loss of seeds during storage. Besides, Catusse et al. (2011) reported that in sugar beet, the abundance of alpha-glucosidase was increased by seed priming but down-regulated by seed aging treatment, which reflected that alpha-glucosidase can be used as an indicator for seed priming and aging. However, research concerning the changes of $\alpha$-amylase activity, total soluble sugar content and the ultrastructure of primed rice seed in response to different storage conditions and storage durations is lacked.

Lipid peroxidation, which is mainly triggered by reactive oxygen species (ROS) in plants cell, could interrupt plants metabolic functions and lead to cell death (Hussain et al., 2016a). Malondialdehyde (MDA) is the end product of lipid peroxidation and could also cause cell damage by reacting with macromolecules (Xu et al., 2015). On the other side, the antioxidant defense systems, which include the antioxidant enzymes such as peroxidase (POD), superoxide dismutase (SOD), and catalase (CAT), have been regarded as the most important defense system to protect the plants from oxidative stress by eliminating the accumulation of ROS (Foyer and Noctor, 2005; Gill and Tuteja, 2010). The strong correlation between antioxidant system and seed aging has been reported by several researches (Zhu and Chen, 2007; Demirkaya et al., 2010). Sung and Jeng (2010) suggested that the ROS could be accumulated during storage with 
the anticipation of oxygen and water. Under mild aging condition (natural aging), the abundance of CAT enzyme in Arabidopsis seeds was largely decreased (Rajjou et al., 2008). For primed seeds, the changes of CAT abundance in response to seed priming and aging have been reported in sugar beet (Catusse et al., 2011). However, the changes of lipid peroxidation level and antioxidant activity in primed rice seeds under various natural storage conditions and durations is still lacking.

Understanding the influences of different storage conditions on longevity of primed rice seeds could provide valuable information on the application of seed priming technology. The aims of this study were (1) to evaluate the effects of temperature (low temperature and room temperature), oxygen (aerobic and vacuum) and $\mathrm{RH}$ (low $\mathrm{RH}$ and high $\mathrm{RH}$ ) on germination and seedling growth attributes of primed and non-primed rice seeds;

(2) to explore the biochemical and morphological changes of primed and non-primed rice seeds stored under different storage conditions and durations.

\section{MATERIALS AND METHODS}

\section{Seed Source}

The rice (O. sativa L.) seeds of a local mega variety Huanghuazhan (HHZ, inbred) were used in present experiment. The initial germination percentage of the seeds was over $95 \%$.

\section{Seed Priming Treatment}

The process of seed priming is soaking the dry seeds into the solution which contained priming agent for $24 \mathrm{~h}$ and then

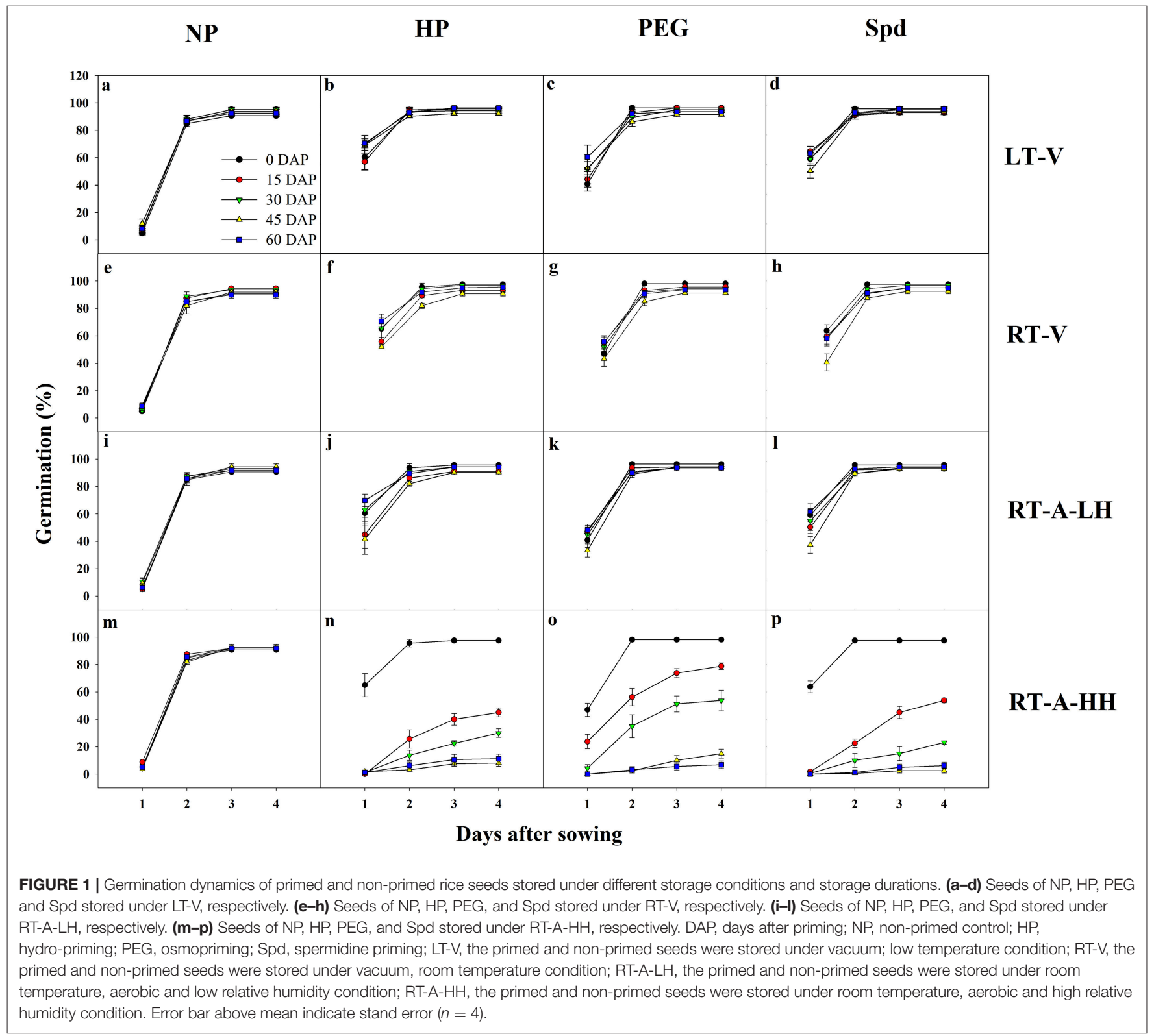


TABLE 2 | Germination percentage, germination index, and vigor index of primed and non-primed seeds stored under different storage conditions and storage durations.

\begin{tabular}{|c|c|c|c|c|c|}
\hline $\begin{array}{l}\text { Priming } \\
\text { treatment }\end{array}$ & $\begin{array}{l}\text { Storage } \\
\text { condition }\end{array}$ & $\begin{array}{l}\text { Storage } \\
\text { duration } \\
\text { (days) }\end{array}$ & $\begin{array}{l}\text { Germination } \\
\text { (\%) }\end{array}$ & $\begin{array}{l}\text { Germination } \\
\text { index }\end{array}$ & $\begin{array}{l}\text { Vigor } \\
\text { index }\end{array}$ \\
\hline \multirow[t]{24}{*}{ NP } & LT-V & 0 & $90.6 \mathrm{~b}$ & $40.15 b$ & $110.12 \mathrm{ab}$ \\
\hline & & 15 & $95.0 \mathrm{a}$ & $42.58 \mathrm{a}$ & $118.91 \mathrm{a}$ \\
\hline & & 30 & $95.0 \mathrm{a}$ & $42.83 a$ & $117.63 a$ \\
\hline & & 45 & $93.8 \mathrm{ab}$ & $44.03 a$ & $113.95 \mathrm{ab}$ \\
\hline & & 60 & $92.5 \mathrm{ab}$ & 42.23ab & $100.20 b$ \\
\hline & & Mean & $93.4 \mathrm{~A}$ & $42.36 \mathrm{~A}$ & $112.11 \mathrm{AB}$ \\
\hline & RT-V & 0 & $90.6 a$ & $40.15 a$ & $110.05 a$ \\
\hline & & 15 & $94.4 \mathrm{a}$ & $42.31 a$ & $111.53 a$ \\
\hline & & 30 & $93.8 \mathrm{a}$ & $41.92 a$ & $124.55 a$ \\
\hline & & 45 & $91.9 a$ & $41.08 a$ & $119.78 a$ \\
\hline & & 60 & $90.0 a$ & $41.53 a$ & $117.60 \mathrm{a}$ \\
\hline & & Mean & $92.1 \mathrm{AB}$ & $41.39 \mathrm{AB}$ & $116.70 \mathrm{~A}$ \\
\hline & RT-A-LH & 0 & $90.6 a$ & $40.15 a$ & $110.03 a$ \\
\hline & & 15 & $93.1 \mathrm{a}$ & $41.23 a$ & $113.78 \mathrm{a}$ \\
\hline & & 30 & $91.9 a$ & $43.19 a$ & $109.78 a$ \\
\hline & & 45 & $94.4 \mathrm{a}$ & $42.90 \mathrm{a}$ & $114.36 a$ \\
\hline & & 60 & $91.9 a$ & $41.06 a$ & $105.67 a$ \\
\hline & & Mean & $92.4 \mathrm{AB}$ & $41.72 \mathrm{~A}$ & $110.73 \mathrm{AB}$ \\
\hline & RT-A-HH & 0 & $90.6 a$ & $40.15 a$ & $110.03 a$ \\
\hline & & 15 & $91.9 a$ & 40.58ab & $110.05 a b$ \\
\hline & & 30 & $91.9 a$ & $40.15 a b$ & $100.55 a b$ \\
\hline & & 45 & $91.9 a$ & $39.83 a b$ & $98.35 a b$ \\
\hline & & 60 & $90.6 a$ & $39.48 b$ & 93.97b \\
\hline & & Mean & $91.8 \mathrm{~B}$ & $40.50 \mathrm{~B}$ & $103.45 \mathrm{~B}$ \\
\hline \multirow[t]{22}{*}{$\mathrm{HP}$} & LT-V & 0 & $97.5 \mathrm{ab}$ & $67.90 a$ & $277.20 a$ \\
\hline & & 15 & $97.5 \mathrm{ab}$ & $66.90 a$ & $250.77 a$ \\
\hline & & 30 & $96.3 a b$ & $71.10 \mathrm{a}$ & $277.05 a$ \\
\hline & & 45 & $94.4 b$ & $69.82 a$ & $266.75 a$ \\
\hline & & 60 & $98.1 \mathrm{a}$ & $71.68 \mathrm{a}$ & $281.45 a$ \\
\hline & & Mean & $96.8 \mathrm{~A}$ & $69.48 \mathrm{~A}$ & $270.64 \mathrm{~A}$ \\
\hline & RT-V & 0 & $97.5 a$ & $67.93 a$ & $277.20 a$ \\
\hline & & 15 & $93.1 \mathrm{ab}$ & $61.97 a b$ & $222.42 \mathrm{bc}$ \\
\hline & & 30 & $96.9 a$ & $67.80 a$ & $251.15 a b$ \\
\hline & & 45 & $90.6 b$ & $58.28 b$ & $212.18 c$ \\
\hline & & 60 & $95.6 a$ & $68.91 \mathrm{a}$ & $270.62 a$ \\
\hline & & Mean & $94.8 \mathrm{~B}$ & $64.94 \mathrm{~B}$ & $246.71 \mathrm{~A}$ \\
\hline & RT-A-LH & 0 & $97.5 \mathrm{a}$ & $67.93 a$ & $277.20 a$ \\
\hline & & 15 & $93.1 \mathrm{~b}$ & $59.75 b$ & $236.38 b c$ \\
\hline & & 30 & $96.3 a$ & $68.13 a$ & $279.55 a$ \\
\hline & & 45 & $92.5 b$ & $57.62 b$ & $217.58 c$ \\
\hline & & 60 & $96.3 a$ & $70.38 a$ & $274 a b$ \\
\hline & & Mean & $95.1 A B$ & $64.75 \mathrm{~B}$ & $256.94 \mathrm{~A}$ \\
\hline & RT-A-HH & 0 & $97.5 \mathrm{a}$ & $67.92 a$ & $277.20 a$ \\
\hline & & 15 & $45.0 \mathrm{~b}$ & $14.98 \mathrm{~b}$ & $24.90 \mathrm{~b}$ \\
\hline & & 30 & $30.0 \mathrm{c}$ & $11.78 b$ & $10.61 b c$ \\
\hline & & 45 & $8.1 d$ & $3.23 c$ & $3.40 \mathrm{bc}$ \\
\hline
\end{tabular}

TABLE 2 | Continued

\begin{tabular}{|c|c|c|c|c|c|}
\hline $\begin{array}{l}\text { Priming } \\
\text { treatment }\end{array}$ & $\begin{array}{l}\text { Storage } \\
\text { condition }\end{array}$ & $\begin{array}{l}\text { Storage } \\
\text { duration } \\
\text { (days) }\end{array}$ & $\begin{array}{l}\text { Germination } \\
(\%)\end{array}$ & $\begin{array}{l}\text { Germination } \\
\text { index }\end{array}$ & $\begin{array}{l}\text { Vigor } \\
\text { index }\end{array}$ \\
\hline & & 60 & $11.3 d$ & $4.31 c$ & $0.63 c$ \\
\hline & & Mean & $38.5 \mathrm{C}$ & $20.44 C$ & $63.34 \mathrm{~B}$ \\
\hline \multirow[t]{24}{*}{ PEG } & LT-V & 0 & $98.1 \mathrm{a}$ & $61.28 a$ & $220.83 a$ \\
\hline & & 15 & $98.1 \mathrm{a}$ & $61.92 \mathrm{a}$ & $228.55 a$ \\
\hline & & 30 & 96.9ab & $63.75 a$ & $239.37 a$ \\
\hline & & 45 & $93.8 b$ & $60.15 a$ & $212.93 a$ \\
\hline & & 60 & $95.6 a b$ & $67.23 a$ & $243.08 a$ \\
\hline & & Mean & $96.5 \mathrm{~A}$ & $62.86 \mathrm{~A}$ & $228.95 A$ \\
\hline & RT-V & 0 & $98.1 a$ & $61.28 a$ & $220.83 b$ \\
\hline & & 15 & $95.6 a b$ & $62.98 a$ & 242.72ab \\
\hline & & 30 & $94.4 b$ & $61.18 a$ & 226.95ab \\
\hline & & 45 & $91.3 c$ & $55.55 b$ & $191.53 c$ \\
\hline & & 60 & $93.8 \mathrm{bc}$ & $62.28 a$ & $243.22 a$ \\
\hline & & Mean & $94.6 \mathrm{~A}$ & $60.65 \mathrm{~B}$ & $225.05 \mathrm{~A}$ \\
\hline & RT-A-LH & 0 & $98.1 \mathrm{a}$ & $61.28 \mathrm{ab}$ & $220.83 a$ \\
\hline & & 15 & $96.3 a$ & $62.63 a$ & 229.70a \\
\hline & & 30 & $95.6 a$ & $61.23 a b$ & $228.13 a$ \\
\hline & & 45 & $96.3 a$ & $56.73 b$ & $221.75 a$ \\
\hline & & 60 & $95.6 a$ & $62.35 a$ & $220.07 a$ \\
\hline & & Mean & $96.4 \mathrm{~A}$ & $60.84 \mathrm{~B}$ & $224.09 A$ \\
\hline & $\mathrm{RT}-\mathrm{A}-\mathrm{HH}$ & 0 & $98.1 \mathrm{a}$ & $61.28 a$ & 220.83a \\
\hline & & 15 & $78.8 b$ & $38.50 \mathrm{~b}$ & $78.13 b$ \\
\hline & & 30 & $53.8 \mathrm{c}$ & $20.95 c$ & $27.22 \mathrm{c}$ \\
\hline & & 45 & $6.9 d$ & $2.08 d$ & $1.85 \mathrm{~d}$ \\
\hline & & 60 & $15.0 d$ & $3.35 d$ & $2.15 d$ \\
\hline & & Mean & $50.5 \mathrm{~B}$ & $25.23 C$ & $66.03 \mathrm{~B}$ \\
\hline \multirow[t]{22}{*}{ Spd } & LT-V & 0 & $97.5 a$ & $67.78 a$ & $266.38 a$ \\
\hline & & 15 & $95.0 a$ & $68.33 a$ & $248.13 a$ \\
\hline & & 30 & $96.9 a$ & $67.03 a$ & $246.40 a$ \\
\hline & & 45 & $95.6 a$ & 63.33a & $232.97 a$ \\
\hline & & 60 & $97.5 a$ & $68.75 a$ & $259.50 a$ \\
\hline & & Mean & $96.5 \mathrm{~A}$ & $67.04 \mathrm{~A}$ & $250.68 \mathrm{~A}$ \\
\hline & RT-V & 0 & $97.5 a$ & $67.78 a$ & $266.38 a$ \\
\hline & & 15 & $95.0 \mathrm{ab}$ & $64.08 a$ & $240.65 a$ \\
\hline & & 30 & $96.9 a b$ & $64.75 a$ & $238.22 a$ \\
\hline & & 45 & $92.5 b$ & $55.35 b$ & 185.50b \\
\hline & & 60 & 95.0ab & $63.68 a$ & 227.08ab \\
\hline & & Mean & $95.4 \mathrm{~A}$ & $63.13 \mathrm{~B}$ & 231.56B \\
\hline & RT-A-LH & 0 & $97.5 a$ & $67.78 \mathrm{a}$ & 266.38a \\
\hline & & 15 & $95.0 \mathrm{a}$ & 63.33ab & $232.82 \mathrm{bc}$ \\
\hline & & 30 & $95.6 a$ & $64.70 a$ & $242.65 a b$ \\
\hline & & 45 & $95.0 \mathrm{a}$ & $58.08 b$ & 207.10c \\
\hline & & 60 & $96.3 a$ & $67.98 a$ & $260.43 a$ \\
\hline & & Mean & $95.8 \mathrm{~A}$ & 64.37B & $241.87 A B$ \\
\hline & $\mathrm{RT}-\mathrm{A}-\mathrm{HH}$ & 0 & $97.5 a$ & $67.78 a$ & 266.38a \\
\hline & & 15 & $53.8 b$ & $16.65 b$ & $24.75 b$ \\
\hline & & 30 & $23.1 \mathrm{c}$ & $6.58 \mathrm{c}$ & $6.60 \mathrm{bc}$ \\
\hline & & 45 & $2.5 d$ & $0.73 d$ & $0.00 \mathrm{c}$ \\
\hline
\end{tabular}

(Continued) 
TABLE 2 | Continued

\begin{tabular}{|c|c|c|c|c|c|}
\hline $\begin{array}{l}\text { Priming } \\
\text { treatment }\end{array}$ & $\begin{array}{l}\text { Storage } \\
\text { condition }\end{array}$ & $\begin{array}{l}\text { Storage } \\
\text { duration } \\
\text { (days) }\end{array}$ & $\begin{array}{l}\text { Germination } \\
(\%)\end{array}$ & $\begin{array}{l}\text { Germination } \\
\text { index }\end{array}$ & $\begin{array}{l}\text { Vigor } \\
\text { index }\end{array}$ \\
\hline & & 60 & $6.3 d$ & $1.53 d$ & $0.00 \mathrm{c}$ \\
\hline & & Mean & $36.6 \mathrm{~B}$ & $18.65 \mathrm{C}$ & $59.55 \mathrm{C}$ \\
\hline & \multirow[t]{3}{*}{$P$-values } & $\begin{array}{l}\text { Priming } \\
\text { treatment }\end{array}$ & $P<0.01$ & $P<0.01$ & $P<0.01$ \\
\hline & & $\begin{array}{l}\text { Storage } \\
\text { condition }\end{array}$ & $P<0.01$ & $P<0.01$ & $P<0.01$ \\
\hline & & $\begin{array}{l}\text { Storage } \\
\text { duration }\end{array}$ & $P<0.01$ & $P<0.01$ & $P<0.01$ \\
\hline
\end{tabular}

Different lowercase letters denote statistical difference between storage durations of a storage condition at the $5 \%$ level according to LSD test. Different uppercase letters denote statistical difference between storage conditions at the 5\% level according to LSD test. NP, non-primed control; HP, hydro-priming; PEG, osmopriming; Spd, spermidine priming; $L T-V$, the primed and non-primed seeds were stored under vacuum, low temperature condition; RT-V, the primed and non-primed seeds were stored under vacuum, room temperature condition; RT-A-LH, the primed and non-primed seeds were stored under room temperature, aerobic and low relative humidity condition; RT-A-HH, the primed and non-primed seeds were stored under room temperature, aerobic and high relative humidity condition.

air-dried until the seed moisture content reduced to $<10 \%$. The seed priming treatments selected for this study were hydropriming (distilled water, HP), osmopriming ( $10 \%$ polyethylene glycol, PEG) and spermidine priming $\left(0.5 \mathrm{mmol} \mathrm{L}^{-1}, \mathrm{Spd}\right)$. Seeds were primed in the dark at $25^{\circ} \mathrm{C}$ for $24 \mathrm{~h}$, with constant gentle agitation, the ratio of seed weight to solution volume (w/v) was 1:5. The priming solution was changed after every $12 \mathrm{~h}$ (Zheng et al., 2016). The non-primed seeds were used as control. After $24 \mathrm{~h}$, the primed seeds were washed with distilled water for $2 \mathrm{~min}$, surface dried by blotting paper and transferred to air dry oven at 25 ? for $48 \mathrm{~h}$ to reduce the moisture content (Hussain et al., 2015). Dried primed and non-primed seeds were then subjected to different seed storage conditions and durations.

\section{Storage Treatment}

Primed and non-primed seeds were stored at four different storage conditions: (1) Low temperature-vacuum (LT-V); (2) Room temperature-vacuum (RT-V); (3) Room temperatureaerobic-low RH (RT-A-LH); (4) Room temperature-aerobic-high $\mathrm{RH}$ (RT-A-HH). For vacuum treatment, the primed and nonprimed rice seeds seed were packed and sealed in aluminum foil bags coated with polyethylene using vacuum sealer. After that, the vacuumed seed bags were transferred to a freezer $(-4$ ?, LT-V) or stored at room temperature (RT-V). For RT$\mathrm{A}-\mathrm{LH}$ treatment, the primed and non-primed rice seeds were packed in mesh bags and stored in glass desiccator (the $\mathrm{RH}$ is around 25\%). For RT-A-HH treatment, the primed and nonprimed rice seeds were packed in mesh bags and stored at room temperature $\left(30^{\circ} \mathrm{C}\right)$. The primed and non-primed seeds were immediately stored under different storage conditions for 0 , $15,30,45,60$ days, respectively. The average temperatures and $\mathrm{RH}$ of each storage condition and duration were presented in Table 1.

\section{Experimentation}

The experiments were conducted during 2016. Forty healthy seeds of each treatment were evenly placed on two layers of filter paper in petri dishes $(14.5 \mathrm{~cm}$ diameter). After adding $20 \mathrm{ml}$ water to each treatment, The petri dishes were transferred to growth chamber with $12 \mathrm{~h}$ light period, and $30^{\circ} \mathrm{C}$ (day): $25^{\circ} \mathrm{C}$ (night temperature). Equal volume of distilled water was applied to all petri dishes when their moisture content decreased. All the experiments were laid out in a completely randomized design with four biological replications.

\section{Observation}

The rice seeds germination was recorded based on the instruction of Association of Official Seed Analysis (1990). Germination percentage was calculated as the ratio of the number of seeds germinated to the total number of seeds. Germination index (GI) was calculated as GI $=\frac{\text { No. of emerged seeds }}{\text { Days of first count }}+--$ $-+\frac{\text { No. of emerged seeds }}{\text { Days of final count }}$. Vigor index (VI) was calculated by multiplying GI with seedling length. At 6 days after sowing (DAS), 10 seedlings were randomly sampled from each treatment and each replication. The root length and fresh weight as well as shoot length and fresh weight of each sample was recorded immediately. Each observation was replicated for four times.

For the determination of $\alpha$-amylase activity, $0.3 \mathrm{~g}$ frozen seedlings (each treatment was replicated for four times) were homogenized and rinsed with $8 \mathrm{ml}$ ice-cold Na-phosphate buffer ( $\mathrm{pH} 7.0,0.1 \mathrm{M}$ ). After centrifuging at 12,000 $\mathrm{g}$ for $20 \mathrm{~min}$, the supernatant was collected as a crude extract. The DNS method was used to determine the $\alpha$-amylase activity (Bernfeld, 1955).

The determination of the total soluble sugar contents was according to the methods of Zheng et al. (2016), $0.3 \mathrm{~g}$ frozen seedling samples of each treatment (with four biological replications) were ground and mixed with $50 \mathrm{ml}$ distilled water. Then the mixture was filtered using Whatman No. 42 filter paper. The total soluble sugar contents in rice seedlings were evaluated by the phenol sulfuric method (Dubois et al., 1956).

The scanning electron microcopy assay was conducted to examine the morphology changes of primed rice seeds after storage. As three priming treatments showed similar response to different storage condition and storage duration. Only one priming treatment (hydro-priming, HP) was selected to conduct the scanning electron microcopy assay. The primed rice seeds that stored under four different conditions for 0,30 and 60 days were incubated at 25 ? for $12 \mathrm{~h}$ and then soaked in liquid nitrogen for $2 \mathrm{~min}$ (Pallwall et al., 1991). The endosperm of the primed rice seeds was cut longitudinally in half with a razor blade and then dehydrated with a series of 30, 50, 70, 80, 90, 95, $100 \%$ ethanol and dried to critical point in a critical-point drying apparatus. After then, the dehydrated samples were coated with gold- palladium for $20 \mathrm{~min}$ in a coating machine. The structure changes of rice endosperms were observed in a scanning electron microscope. 
For the lipid peroxidation and antioxidant enzymes assay, rice seeds were incubated at 25 ? for $24 \mathrm{~h}$, then $0.5 \mathrm{~g}$ fresh samples in each container were grounded with $8 \mathrm{ml}$ of $50 \mathrm{mM}$ phosphate buffer ( $\mathrm{pH} 7.0$, containing 1\% (w/v) polyvinylpyr rolidone) (Zheng et al., 2016). After centrifuging at $15,000 \mathrm{~g}$ for $20 \mathrm{~min}$ at 4 ?. The supernatant was collected as crude extracts for the determination of the SOD, POD, CAT activity and the MDA content. Each assay was replicated for four times. The malondialdehyde (MDA) content was determined by using the method of Zheng et al. (2016). Two milliliter enzyme crude extracts was mixed with $1 \mathrm{ml}$ reaction liquids (consisted of $20 \%$ trichloroacetic acid and $0.5 \%$ thiobarbituric acid). Then the mixture was incubated at 95 ? for $20 \mathrm{~min}$. After cooling to room temperature, the mixture was centrifuged at $10,000 \mathrm{~g}$ for $10 \mathrm{~min}$. The absorbance of supernatant at $532 \mathrm{~nm}$ was determined and the nonspecific absorbance at $600 \mathrm{~nm}$ was subtracted. The MDA content was calculated by the extinction coefficient of $155 \mathrm{mM}^{-1} \mathrm{~cm}^{-1}$ (Zheng et al., 2016).

The CAT activity was determined by the method of Zheng et al. (2016) and Beers and Sizer (1952). $0.5 \mathrm{ml}$ enzyme crude extract was mixed with of $2 \mathrm{ml}$ of sodium phosphate buffer (50 mM, pH 7.0), and $0.5 \mathrm{ml}$ hydrogen peroxide $(40 \mathrm{mM})$. Then the decline in absorbance at $240 \mathrm{~nm}$ was immediately recorded using ultraviolet spectrophotometer (Tecan infinite M200, Switzerland) (Beers and Sizer, 1952). The CAT activity was defined as an absorbance change of 0.01 units per min and expressed as $\mathrm{U} \mathrm{g}^{-1} \mathrm{FW}$ (Zheng et al., 2016).

The POD activity was determined by guaiacol oxidation method with slight modifications (Chance and Maehly, 1995; Zheng et al., 2016). $0.1 \mathrm{ml}$ crude extract was reacted with $2.9 \mathrm{ml}$ reaction mixture which contains $50 \mathrm{mM}$ sodium acetate buffer ( $\mathrm{pH} 5.0$ ), $20 \mathrm{mM}$ guaiacol and $40 \mathrm{mM}$ hydrogen peroxide, and in the blank control, the enzyme extract was replaced by

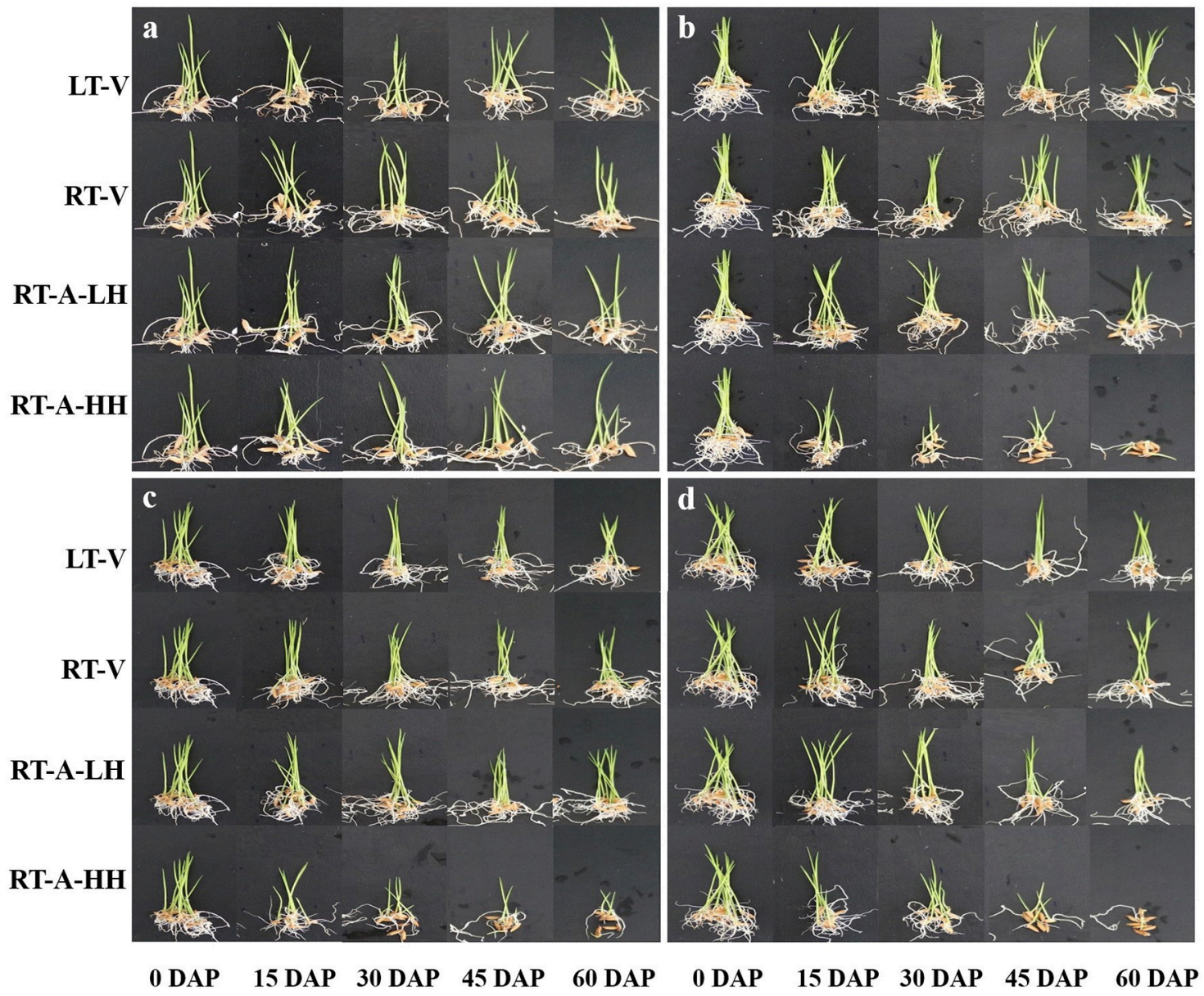

FIGURE 2 | Early growth performance of non-primed and primed rice seedlings under different storage conditions and durations. (a) Non-primed control, (b) Hydro-priming, (c) Osmopriming, (d) Spermidine priming. DAP, days after priming; NP, non-primed control; HP, hydro-priming; PEG, Osmopriming; Spd, spermidine priming; LT-V, the primed and non-primed seeds were stored under vacuum, low temperature condition; RT-V, the primed and non-primed seeds were stored under vacuum, room temperature condition; RT-A-LH, the primed and non-primed seeds were stored under room temperature, aerobic and low relative humidity condition; RT-A-HH, the primed and non-primed seeds were stored under room temperature, aerobic and high relative humidity condition. The figure was merged from 52 pictures. All pictures shown were taken under exactly the same conditions. 
TABLE 3 | Root length, shoot length, root fresh weight, and shoot fresh weight of primed and non-primed seedlings (6 DAS) stored under different storage conditions and storage durations.

\begin{tabular}{|c|c|c|c|c|c|c|}
\hline $\begin{array}{l}\text { Priming } \\
\text { treatment }\end{array}$ & $\begin{array}{l}\text { Storage } \\
\text { condition }\end{array}$ & $\begin{array}{l}\text { Storage } \\
\text { duration }\end{array}$ & $\begin{array}{l}\text { Root } \\
\text { length } \\
\text { (cm) }\end{array}$ & $\begin{array}{l}\text { Shoot } \\
\text { length } \\
\text { (cm) }\end{array}$ & $\begin{array}{l}\text { Fresh } \\
\text { root } \\
\text { weight } \\
\text { (mg) }\end{array}$ & $\begin{array}{l}\text { Fresh } \\
\text { shoot } \\
\text { weight } \\
\text { (mg) }\end{array}$ \\
\hline \multirow[t]{24}{*}{ NP } & LT-V & 0 & $4.4 a$ & $2.7 a$ & $8.34 a$ & $11.74 a$ \\
\hline & & 15 & $4.2 \mathrm{a}$ & $2.8 \mathrm{a}$ & $9.28 a$ & $11.20 \mathrm{a}$ \\
\hline & & 30 & $4.4 a$ & $2.7 a$ & $9.84 a$ & $12.22 \mathrm{a}$ \\
\hline & & 45 & $4.0 \mathrm{a}$ & $2.6 a$ & $8.63 a$ & $11.14 \mathrm{a}$ \\
\hline & & 60 & $4.7 a$ & $2.4 a$ & $8.08 a$ & $10.37 a$ \\
\hline & & Mean & $4.4 \mathrm{~A}$ & $2.6 \mathrm{~A}$ & $8.82 \mathrm{~A}$ & $11.33 \mathrm{~A}$ \\
\hline & RT-V & 0 & $4.4 a$ & $2.7 a$ & $8.34 a$ & $11.74 \mathrm{a}$ \\
\hline & & 15 & $4.5 \mathrm{a}$ & $2.6 a$ & $9.05 a$ & $11.08 a$ \\
\hline & & 30 & $4.4 a$ & $3.0 \mathrm{a}$ & $9.31 a$ & $12.26 \mathrm{a}$ \\
\hline & & 45 & $4.0 \mathrm{a}$ & $2.9 a$ & $8.15 a$ & $11.81 a$ \\
\hline & & 60 & $3.6 a$ & $2.8 \mathrm{a}$ & $7.68 \mathrm{a}$ & $11.84 \mathrm{a}$ \\
\hline & & Mean & $4.2 \mathrm{AB}$ & $2.8 \mathrm{~A}$ & $8.51 \mathrm{AB}$ & $11.75 \mathrm{~A}$ \\
\hline & RT-A-LH & 0 & $4.4 a$ & $2.7 a$ & $8.34 a$ & $11.74 a$ \\
\hline & & 15 & $3.8 \mathrm{a}$ & $2.8 \mathrm{a}$ & $9.14 a$ & $10.70 \mathrm{a}$ \\
\hline & & 30 & $4.5 \mathrm{a}$ & $2.5 a$ & $8.15 a$ & $11.65 \mathrm{a}$ \\
\hline & & 45 & $4.5 a$ & $2.6 a$ & $6.47 a$ & $10.97 a$ \\
\hline & & 60 & $3.8 \mathrm{a}$ & $2.6 a$ & $7.25 \mathrm{a}$ & $11.20 \mathrm{a}$ \\
\hline & & Mean & $4.2 A B$ & $2.7 \mathrm{~A}$ & $7.93 \mathrm{~B}$ & $11.25 \mathrm{~A}$ \\
\hline & RT-A-HH & 0 & $4.4 a$ & $2.7 \mathrm{a}$ & $8.34 a$ & $11.74 a$ \\
\hline & & 15 & $3.8 \mathrm{ab}$ & $2.7 \mathrm{a}$ & $7.81 a$ & $11.67 a$ \\
\hline & & 30 & $3.6 b$ & $2.4 a$ & $8.07 a$ & $11.60 \mathrm{a}$ \\
\hline & & 45 & $4.3 \mathrm{ab}$ & $2.5 a$ & $9.16 \mathrm{a}$ & $11.15 a$ \\
\hline & & 60 & 4.3ab & $2.5 a$ & $7.74 a$ & $10.87 a$ \\
\hline & & Mean & $4.1 \mathrm{~B}$ & $2.6 \mathrm{~A}$ & $8.22 \mathrm{AB}$ & $11.41 \mathrm{~A}$ \\
\hline \multirow[t]{21}{*}{ HP } & LT-V & 0 & $6.0 a$ & $4.1 \mathrm{a}$ & $13.66 \mathrm{a}$ & $16.07 a$ \\
\hline & & 15 & $5.5 a$ & $3.8 a$ & $11.73 a$ & $14.02 \mathrm{a}$ \\
\hline & & 30 & $5.2 a$ & $3.9 a$ & $13.08 a$ & $15.45 a$ \\
\hline & & 45 & $5.9 a$ & $3.8 a$ & $13.68 \mathrm{a}$ & $14.03 a$ \\
\hline & & 60 & $6.2 a$ & $3.9 a$ & $14.21 a$ & $16.30 a$ \\
\hline & & Mean & $5.8 \mathrm{~A}$ & $3.9 \mathrm{~A}$ & $13.28 \mathrm{~A}$ & $15.19 \mathrm{~A}$ \\
\hline & RT-V & 0 & 6.0ab & $4.1 a$ & 13.66ab & $16.07 a$ \\
\hline & & 15 & $4.9 \mathrm{~b}$ & $3.6 a$ & $11.78 \mathrm{~b}$ & $14.25 a$ \\
\hline & & 30 & $5.4 \mathrm{ab}$ & $3.7 a$ & 13.91ab & $14.20 \mathrm{a}$ \\
\hline & & 45 & $5.0 \mathrm{ab}$ & $3.6 a$ & $11.79 \mathrm{~b}$ & $13.69 a$ \\
\hline & & 60 & $6.0 a$ & $3.9 a$ & $14.79 a$ & $15.38 \mathrm{a}$ \\
\hline & & Mean & $5.5 \mathrm{~A}$ & $3.8 \mathrm{~A}$ & $13.20 \mathrm{~A}$ & $14.73 \mathrm{~A}$ \\
\hline & RT-A-LH & 0 & $6.0 a$ & $4.1 a$ & 13.66ab & $16.07 a$ \\
\hline & & 15 & $5.4 a$ & $3.9 a$ & 13.79ab & $14.15 \mathrm{a}$ \\
\hline & & 30 & $5.6 a$ & $4.1 \mathrm{a}$ & $14.00 \mathrm{a}$ & $15.00 \mathrm{a}$ \\
\hline & & 45 & $5.4 a$ & $3.8 \mathrm{a}$ & $13.08 \mathrm{~b}$ & $13.99 a$ \\
\hline & & 60 & $5.5 a$ & $3.9 a$ & 13.71ab & $14.77 \mathrm{a}$ \\
\hline & & Mean & $5.6 \mathrm{~A}$ & $4.0 \mathrm{~A}$ & $13.67 \mathrm{~A}$ & $14.80 \mathrm{~A}$ \\
\hline & RT-A-HH & 0 & $6.0 \mathrm{a}$ & $4.1 \mathrm{a}$ & $13.66 a$ & $16.07 a$ \\
\hline & & 15 & $1.8 b$ & $1.7 \mathrm{~b}$ & $2.80 \mathrm{~b}$ & $7.04 b$ \\
\hline & & 30 & $1.4 \mathrm{c}$ & $1.0 \mathrm{c}$ & $2.41 \mathrm{bc}$ & $6.14 c$ \\
\hline
\end{tabular}

TABLE 3 | Continued

\begin{tabular}{|c|c|c|c|c|c|c|}
\hline $\begin{array}{l}\text { Priming } \\
\text { treatment }\end{array}$ & $\begin{array}{l}\text { Storage } \\
\text { condition }\end{array}$ & $\begin{array}{l}\text { Storage } \\
\text { duration }\end{array}$ & $\begin{array}{l}\text { Root } \\
\text { length } \\
\text { (cm) }\end{array}$ & $\begin{array}{l}\text { Shoot } \\
\text { length } \\
\text { (cm) }\end{array}$ & $\begin{array}{l}\text { Fresh } \\
\text { root } \\
\text { weight } \\
\text { (mg) }\end{array}$ & $\begin{array}{l}\text { Fresh } \\
\text { shoot } \\
\text { weight } \\
\text { (mg) }\end{array}$ \\
\hline & & 45 & $1.1 \mathrm{c}$ & $1.1 \mathrm{c}$ & $0.91 \mathrm{c}$ & $1.96 \mathrm{c}$ \\
\hline & & 60 & $0.2 \mathrm{c}$ & $0.1 \mathrm{c}$ & $0.45 c$ & $0.89 \mathrm{c}$ \\
\hline & & Mean & $2.1 \mathrm{~B}$ & $1.6 \mathrm{~B}$ & $4.05 \mathrm{~B}$ & $6.44 \mathrm{~B}$ \\
\hline \multirow[t]{24}{*}{ PEG } & LT-V & 0 & $5.5 a$ & $3.6 a$ & $12.72 a$ & $15.22 \mathrm{a}$ \\
\hline & & 15 & $5.7 a$ & $3.7 a$ & $12.98 a$ & $15.13 a$ \\
\hline & & 30 & $5.5 a$ & $3.8 a$ & $13.30 a$ & $14.04 a$ \\
\hline & & 45 & $5.4 a$ & $3.6 a$ & $14.55 a$ & $14.89 a$ \\
\hline & & 60 & $5.8 a$ & $3.6 a$ & $13.08 \mathrm{a}$ & $13.99 a$ \\
\hline & & Mean & $5.6 \mathrm{~A}$ & $3.6 \mathrm{~A}$ & 13.34A & $14.66 \mathrm{~A}$ \\
\hline & RT-V & 0 & $5.5 a$ & $3.6 a$ & $12.72 \mathrm{c}$ & $15.22 a$ \\
\hline & & 15 & $5.7 a$ & $3.9 a$ & $14.14 a$ & $15.54 a$ \\
\hline & & 30 & $5.9 a$ & $3.7 a$ & 13.43ab & $14.48 a$ \\
\hline & & 45 & $5.4 a$ & $3.5 a$ & $13.02 \mathrm{bc}$ & $14.05 a$ \\
\hline & & 60 & $5.8 a$ & $3.9 a$ & $13.22 \mathrm{abc}$ & $14.42 a$ \\
\hline & & Mean & $5.6 \mathrm{~A}$ & $3.7 \mathrm{~A}$ & $13.31 \mathrm{~A}$ & $14.75 \mathrm{~A}$ \\
\hline & RT-A-LH & 0 & $5.5 a b$ & $3.6 a$ & $12.72 \mathrm{a}$ & $15.22 \mathrm{a}$ \\
\hline & & 15 & $5.8 \mathrm{ab}$ & $3.7 a$ & $13.10 a$ & $14.31 a$ \\
\hline & & 30 & $5.4 a b$ & $3.7 a$ & $14.84 a$ & $14.78 a$ \\
\hline & & 45 & $5.2 \mathrm{~b}$ & $3.9 a$ & $14.04 a$ & $14.83 a$ \\
\hline & & 60 & $5.9 a$ & $3.5 a$ & $13.18 a$ & $13.69 a$ \\
\hline & & Mean & $5.6 \mathrm{~A}$ & $3.7 \mathrm{~A}$ & $13.58 \mathrm{~A}$ & $14.57 \mathrm{~A}$ \\
\hline & RT-A-HH & 0 & $5.5 a$ & $3.6 a$ & $12.72 a$ & $15.22 a$ \\
\hline & & 15 & $3.1 b$ & $2.1 \mathrm{~b}$ & $7.57 \mathrm{~b}$ & $9.82 \mathrm{~b}$ \\
\hline & & 30 & $1.5 \mathrm{c}$ & $1.2 \mathrm{c}$ & $3.52 \mathrm{bc}$ & $5.45 c$ \\
\hline & & 45 & $0.5 c$ & $0.4 c$ & $1.47 \mathrm{c}$ & $2.23 \mathrm{c}$ \\
\hline & & 60 & $0.3 c$ & $0.6 c$ & $0.49 c$ & $1.93 \mathrm{c}$ \\
\hline & & Mean & $2.2 \mathrm{~B}$ & $1.6 \mathrm{~B}$ & $5.16 \mathrm{~B}$ & $6.94 \mathrm{~B}$ \\
\hline \multirow[t]{19}{*}{ Spd } & LT-V & 0 & $5.2 \mathrm{ab}$ & $3.9 a$ & $13.32 a$ & $13.35 a$ \\
\hline & & 15 & $4.9 b$ & $3.6 a$ & $12.30 a$ & $12.93 a$ \\
\hline & & 30 & $4.9 b$ & $3.7 a$ & $13.48 a$ & $14.28 a$ \\
\hline & & 45 & $5.2 \mathrm{ab}$ & $3.7 a$ & $13.40 a$ & $13.82 a$ \\
\hline & & 60 & $5.6 a$ & $3.8 a$ & $12.72 \mathrm{a}$ & $13.82 a$ \\
\hline & & Mean & $5.1 \mathrm{~A}$ & $3.7 \mathrm{~A}$ & $13.05 \mathrm{~A}$ & $13.65 \mathrm{~A}$ \\
\hline & RT-V & 0 & $5.2 a$ & $3.9 a$ & $13.32 a$ & $13.35 a$ \\
\hline & & 15 & $5.1 a$ & $3.8 a$ & $13.27 a$ & $14.06 \mathrm{a}$ \\
\hline & & 30 & $4.8 \mathrm{ab}$ & $3.7 a$ & $12.27 a$ & $13.16 a$ \\
\hline & & 45 & $4.3 \mathrm{~b}$ & 3.3a & $12.03 a$ & $12.75 a$ \\
\hline & & 60 & $5.3 a$ & $3.6 a$ & $12.52 \mathrm{a}$ & $13.56 a$ \\
\hline & & Mean & $5.0 \mathrm{~A}$ & $3.8 \mathrm{~A}$ & $13.70 \mathrm{~A}$ & $13.40 \mathrm{~A}$ \\
\hline & RT-A-LH & 0 & $5.2 \mathrm{ab}$ & $3.9 a$ & $13.32 a$ & $13.35 a$ \\
\hline & & 15 & $5.3 a b$ & $3.7 a$ & $13.31 a$ & $14.82 a$ \\
\hline & & 30 & $5.1 \mathrm{ab}$ & $3.8 a$ & $13.08 a$ & $13.92 a$ \\
\hline & & 45 & $4.6 b$ & $3.6 a$ & $12.28 \mathrm{a}$ & $13.70 \mathrm{a}$ \\
\hline & & 60 & $5.9 a$ & $3.8 a$ & $13.66 a$ & $14.63 a$ \\
\hline & & Mean & $5.2 \mathrm{~A}$ & $3.8 \mathrm{~A}$ & $13.13 \mathrm{~A}$ & $14.10 \mathrm{~A}$ \\
\hline & $\mathrm{RT}-\mathrm{A}-\mathrm{HH}$ & 0 & $5.2 a$ & $3.9 a$ & $13.32 a$ & $13.35 a$ \\
\hline
\end{tabular}


TABLE 3 | Continued

\begin{tabular}{lllllll}
\hline $\begin{array}{l}\text { Priming } \\
\text { treatment }\end{array}$ & $\begin{array}{l}\text { Storage } \\
\text { condition }\end{array}$ & $\begin{array}{l}\text { Storage } \\
\text { duration }\end{array}$ & $\begin{array}{l}\text { Root } \\
\text { length } \\
\text { (cm) }\end{array}$ & $\begin{array}{l}\text { Shoot } \\
\text { length } \\
\text { (cm) }\end{array}$ & $\begin{array}{l}\text { Fresh } \\
\text { root } \\
\text { weight } \\
\text { (mg) }\end{array}$ & $\begin{array}{l}\text { Fresh } \\
\text { shoot } \\
\text { weight } \\
\text { (mg) }\end{array}$ \\
\hline & 15 & $2.0 \mathrm{~b}$ & $1.5 \mathrm{~b}$ & $3.01 \mathrm{~b}$ & $6.16 \mathrm{~b}$ \\
& 30 & $0.7 \mathrm{c}$ & $0.8 \mathrm{~b}$ & $2.22 \mathrm{c}$ & $2.94 \mathrm{c}$ \\
& 45 & $0.0 \mathrm{~d}$ & $0.0 \mathrm{c}$ & $0.00 \mathrm{~d}$ & $0.00 \mathrm{~d}$ \\
& 60 & $0.1 \mathrm{~d}$ & $0.0 \mathrm{c}$ & $0.00 \mathrm{~d}$ & $0.00 \mathrm{~d}$ \\
& Mean & $1.6 \mathrm{~B}$ & $1.3 \mathrm{~B}$ & $3.72 \mathrm{~B}$ & $4.50 \mathrm{~B}$ \\
\hline
\end{tabular}

Different lowercase letters denote statistical difference between storage durations of a storage condition at the $5 \%$ level according to LSD test. Different uppercase letters denote statistical difference between storage conditions at the 5\% level according to LSD test. $D A S$, days after sowing; NP, non-primed control; HP, hydro-priming; PEG, osmopriming; Spd, spermidine priming; LT-V, the primed and non-primed seeds were stored under vacuum, low temperature condition; $R T-V$, the primed and non-primed seeds were stored under vacuum, room temperature condition; RT-A-LH, the primed and non-primed seeds were stored under room temperature, aerobic and low relative humidity condition; RT-A$\mathrm{HH}$, the primed and non-primed seeds were stored under room temperature, aerobic and high relative humidity condition.

sodium acetate buffer. The absorbance changes at $470 \mathrm{~nm}$ were recorded using ultraviolet spectrophotometer (Tecan infinite M200, Switzerland) within 3 min after the start of the reaction. One unit POD activity was defined as an absorbance change of 0.01 units per min and was expressed as $\mathrm{U} \mathrm{g}^{-1} \mathrm{FW}$ (Zheng et al., 2016).

The SOD activity was evaluated by nitro blue tetrazolium (NBT) methods with slight modifications (Zheng et al., 2016). $0.3 \mathrm{ml}$ enzyme crude extract was reacted with $2.7 \mathrm{ml}$ reaction mixture that consisted of $1.5 \mathrm{ml}$ phosphate buffer $(50 \mathrm{mM}$, $\mathrm{pH} 7.8), 0.3 \mathrm{ml}$ methionine $(130 \mathrm{mM}), 0.3 \mathrm{ml}$ NBT $(750 \mu \mathrm{M})$, $0.3 \mathrm{ml}$ EDTA $[100 \mu \mathrm{M}), 0.3 \mathrm{ml}$ riboflavin $(20 \mu \mathrm{M})]$ (Zheng et al., 2016). The reaction solution were irradiated under a light bar (15 fluorescent lamps) at $78 \mu \mathrm{mol} \mathrm{m} \mathrm{m}^{-2} \mathrm{~s}^{-1}$ for $15 \mathrm{~min}$. The absorbance of the irradiated and non-irradiated solution at $560 \mathrm{~nm}$ was determined with a spectrophotometer (Tecan infinite M200, Switzerland). One unit of SOD activity was defined as the amount of enzyme that gives $50 \%$ inhibition of NBT photoreduction and was presented as $\mathrm{U} \mathrm{g}^{-1} \mathrm{FW}$ (Zheng et al., 2016).

\section{Statistics Analysis}

All data from present experiment are expressed as the mean value of four biological replications. Statistix 11.0 was used to analyze the data using least significant difference (LSD) test at 0.05 probability level.

\section{RESULTS \\ Germination}

Germination dynamics of primed and non-primed rice seeds regarding different storage conditions and storage durations were presented in Figure 1. For non-primed seeds, no significant difference was found on germination dynamics among various storage conditions and storage durations. Similarly, the germination of the primed seeds stored under LT-V, RT-V and
RT-A-LH did not decrease after 60 days of storage. However, under RT-A-HH, significant decreases in germination speed and germination percentage was observed after 15 days of storage, and the germination decreased drastically with prolonged storage durations. All three priming treatments showed similar responses to different storage conditions and durations.

Significant $(P<0.05)$ variations of storage condition and storage duration on germination attributes of primed rice seeds were recorded (Table 2). When averaged across three priming treatments, the germination percentage, GI and VI of primed seeds stored under LT-V for 60 days were 97.1, 69.2, and 261.3, respectively, which showed no significant difference to that of the un-stored primed seeds. Likewise, the germination attributes of the primed seeds stored under RT-V and RT-A-LH were not decreased during 0-60 days of storage. However, when the primed-seeds were stored under RT-A-HH, all the germination attributes were considerably decreased. When averaged across three priming treatments, the germination percentage, GI and VI of the primed seeds stored under RT-A-HH for 15 days were decreased by $39.4,64.4$, and $83.3 \%$ respectively as compared with that of un-stored primed seeds. When the storage duration extended to 60 days, the germination percentage, GI and VI of primed seeds stored under RT-A-HH were decreased by 88.9, 95.3, and 99.6\%, respectively as compared with un-stored primed seeds.

\section{Seedling Growth}

A pictorial illustration of primed and non-primed rice seedlings (6 DAS) stored under different storage durations and storage conditions is presented in Figure 2. Consistent with germination attributes, no significant difference was found in seedling growth attributes of non-primed rice seedlings stored under different storage conditions and durations (Table 3). For primed rice seeds, significant $(P<0.05)$ effects of storage conditions and storage durations on seedling growth were observed (Table 3 ). When stored under LT-V, RT-V, and RT-A-LH, the seedling growth attributes did not decrease when seeds were stored for 60 days. Nevertheless, the seedling growth attributes of primed rice seeds stored under RT-A-HH were significantly decreased were stored for 15 days. When averaged across three priming treatments, the root length, root fresh weight, shoot length, shoot fresh weight of the primed rice seedlings stored under RT-A-HH for 15 days were decreased by 58.3, 37.5, 156.7, and $128.7 \%$, respectively. Further increase of storage duration brought concomitant decreases in seedling growth attributes of primed seed. Averaged across three priming treatments, root length, root fresh weight, shoot length and shoot fresh weight of the rice seedlings stored under RT-A-HH were decreased by $69.4-95.8 \%, 39.3-64.9 \%, 119.7-230.7 \%$, and $128.7-248.9 \%$, respectively when seed storage duration was prolonged from 15 days to 60 days, compared with that of un-stored control (Table 3).

\section{Starch Metabolism}

Starch metabolism in rice seeds and seedlings was reflected by the $\alpha$-amylase activity and total soluble sugar content during seed germination (Figures 3, 4). For the non-primed seeds, 


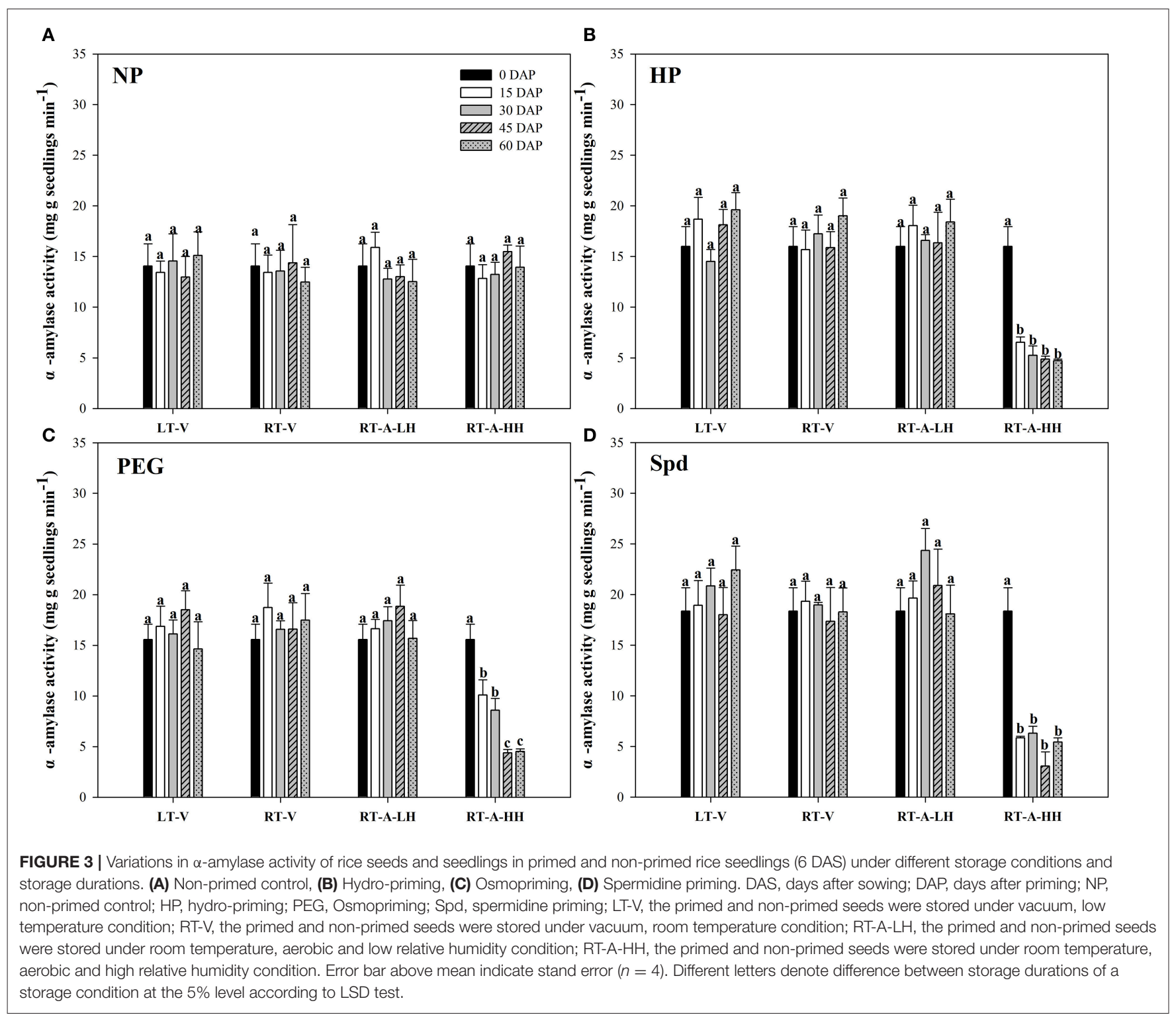

$\alpha$-amylase activity and total soluble sugar content in primed rice seedlings showed no significant difference among different storage durations and storage conditions. In contrary, significant variations $(P<0.05)$ in starch metabolism of primed rice seeds stored under various storage conditions and durations were found. When the primed seeds were stored under LT-V, RT-V, RT-A-LH for 60 days, no significant decreases were observed in $\alpha$-amylase activity and total soluble sugar content in rice seedlings, as compared with un-stored control. However, $\alpha$ amylase activity and total soluble sugar content in rice seedlings were significantly decreased when stored at RT-A-HH for even only 15 days. When averaged across priming treatments, the $\alpha$-amylase activity in rice seedlings decreased by 55.0, 59.6, 75.3, and $70.6 \%$ stored for 15-60 days respectively, as compared with 0 DAP control. The total soluble sugar contents in primed rice seedlings showed the similar trends to that of $\alpha$-amylase activity. The seeds stored under RT-A-HH exhibited the lowest $\alpha$-amylase activity and total soluble sugar content among four storage conditions. When averaging across priming treatments and storage durations, the $\alpha$-amylase activity of rice seedlings stored under RT-A-HH was decreased by 55.1, 54.0, and $55.7 \%$, respectively, while the total soluble sugar content was decreased by $51.3,49.3$, and $49.4 \%$ respectively as compared with that under LT-V, RT-V, RT-A-LH.

\section{Scanning Electron Microscopy}

Structural changes in endosperms of primed rice seeds stored under different conditions and durations are presented in Figure 5. For the un-stored primed rice seeds (0 DAP), the starch was accumulated as compound starch grains and no cavity was observed in the endosperm. No obvious changes were found when the primed rice seeds were stored under LT-V (Figures 5b,f), RT-V (Figures 5c,g) and RT-A-LH (Figures 5c,h) for 30 and 60 days, compared with that of the un-stored seeds 


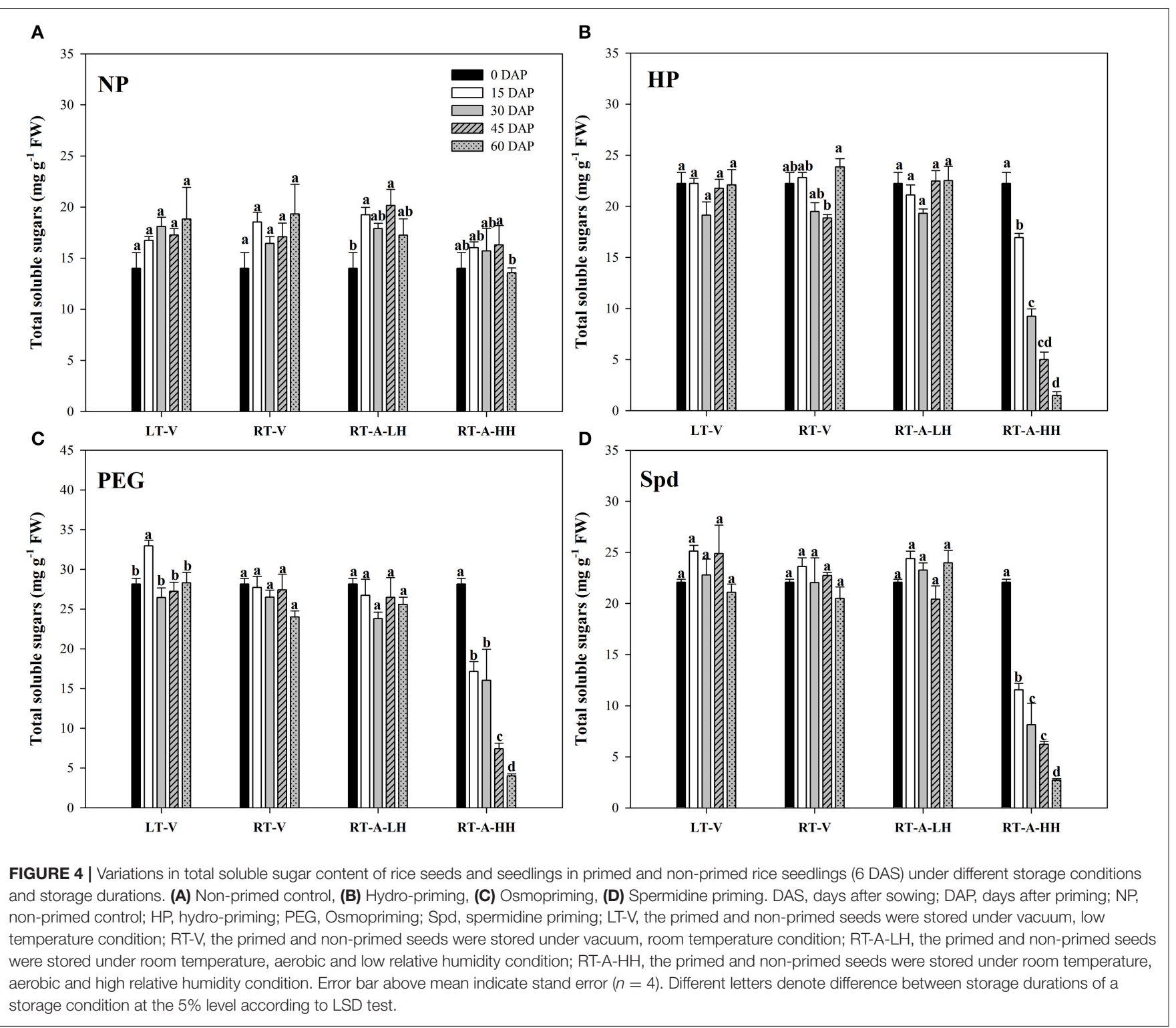

(Figure 5a). Nevertheless, storage of primed seeds under RT-A$\mathrm{HH}$ resulted in severely consumption of stored reserves in seed endosperms. When the primed seeds were stored under RT-A$\mathrm{HH}$ for 30 days, the starch grains began to digest into tiny starch granules (Figure 5e). When the storage duration extended to 60 days, the structure of the starch granules were severely destroyed as the surface of the starch grains became rough and irregular, small holes and the cavities between the embryo and endosperm can be observed (Figure 5i).

\section{Lipid Peroxidation}

No significant difference was found in MDA contents when the non-primed rice seeds were stored under different storage conditions and durations (Figure 6). Similar results were also observed for the primed rice seeds stored at LT-V, RT-V and RTA-LH (Figure 6). Nevertheless, storage of primed rice seeds at RT-A-HH for 15 days significantly increased the MDA contents in rice seeds. Further increase of storage duration brought concomitant increases of MDA contents in primed rice seeds. When averaged across priming treatments, the MDA contents in rice seeds increased by $13.58,46.63,78.78$, and $104.44 \%$, when stored for $15,30,45$, and 60 days respectively, as compared with 0 DAP treatment.

\section{Antioxidant Enzymes}

The activity of antioxidant enzymes (SOD, CAT, POD) in primed and non-primed rice seeds stored under various conditions and durations are presented in Figures 7-9. Consistent with the lipid peroxidation levels, the antioxidant enzymes activity in non-primed rice seeds showed no significant difference among various storage durations and conditions. Similarly, the SOD, CAT, and POD activity of primed seeds stored under LT-V, RT-V, and RT-A-LH for 60 days were not decreased as compared with that of the un-stored control. However, when the 

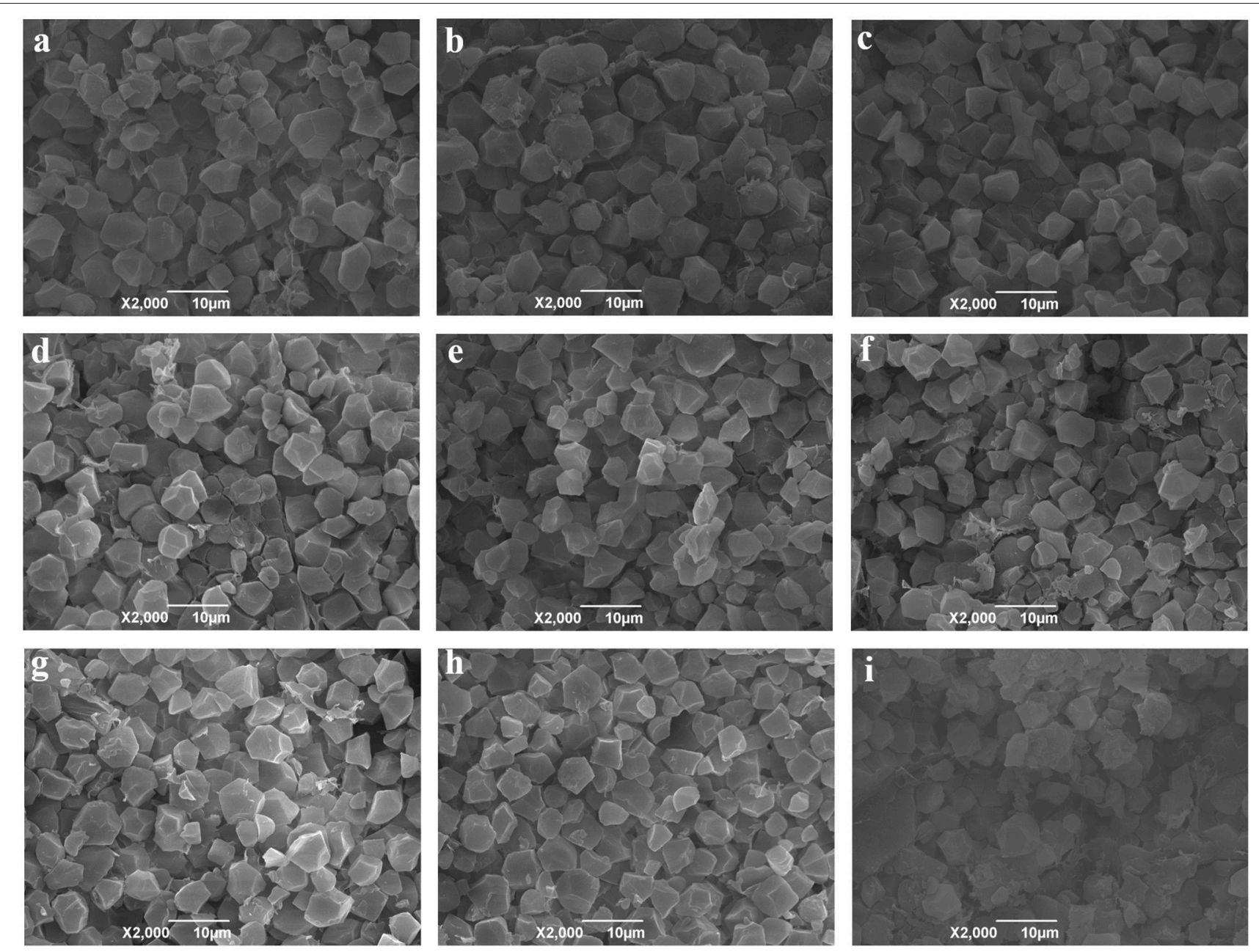

FIGURE 5 | Starch granule in endosperms of hydro-primed rice seeds stored under LT-V, RT-V, RT-A-LH, and RT-A-HH for 0, 30,60 days. (a) 0 DAP control, (b) 30 DAP under LT-V, (c) 30 DAP under RT-V, (d) 30 DAP under RT-A-LH, (e) 30 DAP under RT-A-HH, (f) 60 DAP under LT-V,(g) 60 DAP under RT-V, (h) 60 DAP under RT-A-LH, (i) 60 DAP under RT-A-HH. DAP, days after priming; LT-V, the primed and non-primed seeds were stored under vacuum, low temperature condition; RT-V, the primed and non-primed seeds were stored under vacuum, room temperature condition; RT-A-LH, the primed and non-primed seeds were stored under room temperature, aerobic and low relative humidity condition; $\mathrm{RT}-\mathrm{A}-\mathrm{HH}$, the primed and non-primed seeds were stored under room temperature, aerobic and high relative humidity condition.

primed-seeds were stored under RT-A-HH, all the antioxidants enzymes activities were significantly decreased. When averaged across three priming treatments, the SOD, CAT and POD activity of the primed seeds stored under RT-A-HH for 15 days were decreased by $28.84,34.44$, and $60.48 \%$ respectively as compared with that of un-stored control. When the storage duration was extended from 15 to 60 days, the SOD, CAT, and POD activity of the primed rice seeds stored under RTA-HH were decreased by $34.94-47.00 \%, 48.44-64.73 \%$, and $67.98-74.94 \%$, respectively, as compared with that of un-stored control.

\section{DISCUSSION}

In the present study, increasing storage temperature did not reduce the viability of primed and non-primed rice seeds stored under vacuum condition within 60 days of storage. In contrast, it has been suggested that the seed deterioration during storage was temperature dependent in brassicaceae species (Mira et al., 2015). The interrelationship between seed moisture content and storage temperature plays more important role in influencing seed viability during storage. Hill et al. (2007) revealed that primed lettuce seeds stored at $9 \%$ seed moisture content and 38.8 ? deteriorated faster than primed seeds stored at $6 \%$ seed moisture content at 48.8 ?. This suggested the more important role of seed moisture content than temperature in influencing seed longevity during storage. In present study, the moisture contents of primed and non-primed seeds were kept under $10 \%$ before storage. The viability of primed and unprimed rice seeds were not reduced under RT-V, probably because vacuum treatment enables seeds to keep low moisture content as oxygen and water was isolated from the storage condition. Moreover, the seed respiration might be 


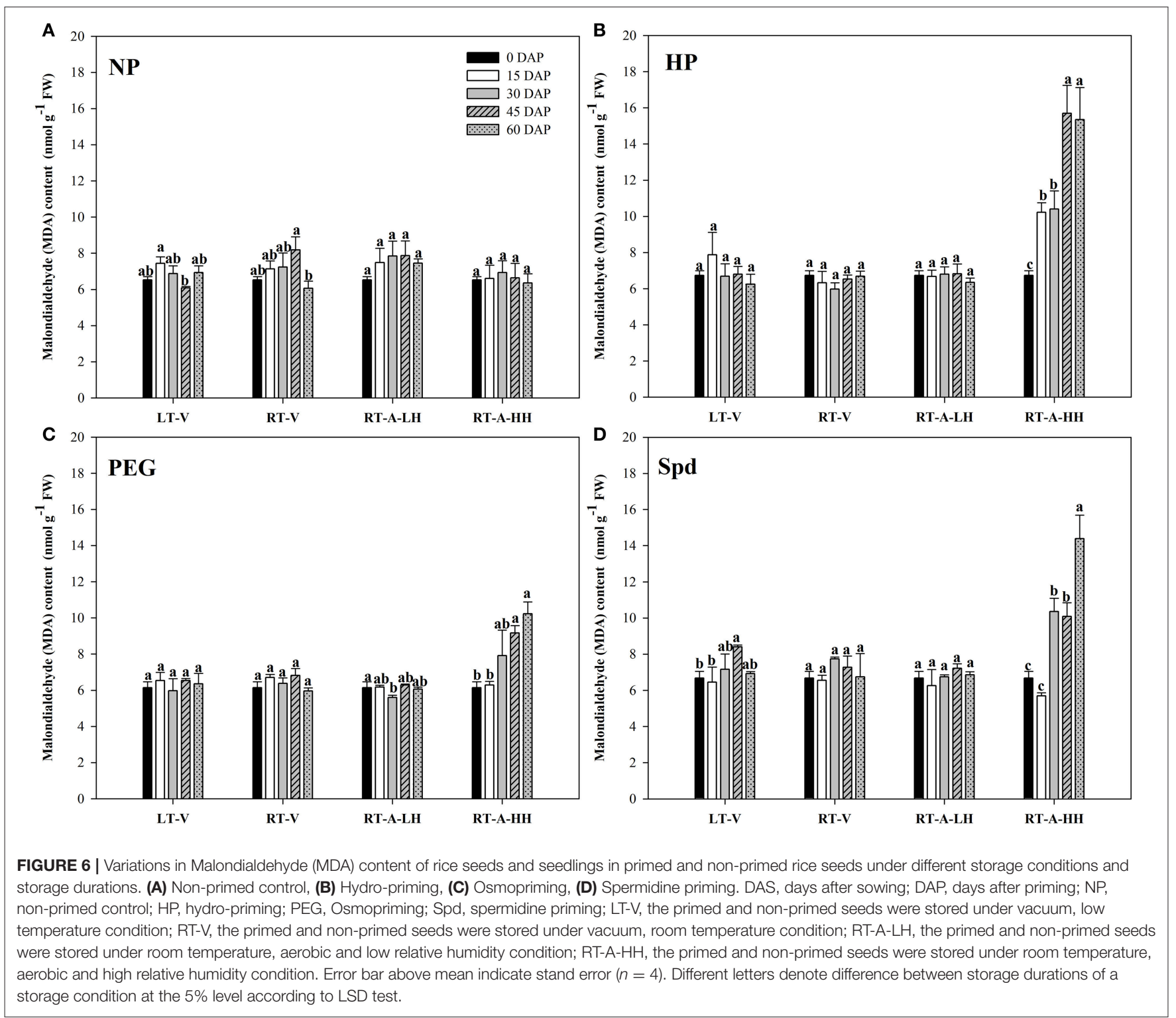

largely reduced with low seed moisture and the absence of oxygen (Hu et al., 2006). Previously, the beneficial effect of vacuum storage has been observed by several researches. Feng et al. (2017) reported that the moisture content of $P$. grandiflorum seeds did not increase after 10 months of vacuum storage. The beneficial effect of vacuum storage on extending the seed longevity has also been reported in sweet corn seeds (Chiu et al., 2003). Yeh et al. (2005) reported that the longevity of primed bitter gourd seeds were markedly decreased after 12 months storage under ambient oxygen condition, but seed viability was kept under partial vacuum storage condition. Even with high seed moisture content, the deterioration of rice seeds can be delayed for a few weeks at $30^{\circ} \mathrm{C}$ by vacuum storage (Kaloyereas, 1955). The results of present work suggested that the primed rice seeds can be stored under vacuum condition for 60 days at room temperature if the seed moisture content was below $10 \%$. However, the effect of vacuum storage might be varied among different species, seed moisture contents and storage temperatures. Quantitative evaluation of vacuum storage of primed seeds in response to different seed moisture contents and temperatures needs to be addressed.

At low $\mathrm{RH}$ and room temperature, the storage of primed seeds under aerobic environment did not reduce seed longevity during 60 days of storage. As no significant variance was found in germination and seedling growth attributes between RT-V and RT-A-LH. Storage of seeds under aerobic condition has been reported to result in several changes caused by respiration, such as the depletion of food reserves (proteins and sugar contents), which were considered to be responsible for seed aging (Calucci et al., 2004). Schwember and Bradford (2011) reported that storage of primed lettuce in aerobic condition seeds accelerated the seed deterioration as compared with that of anaerobic 

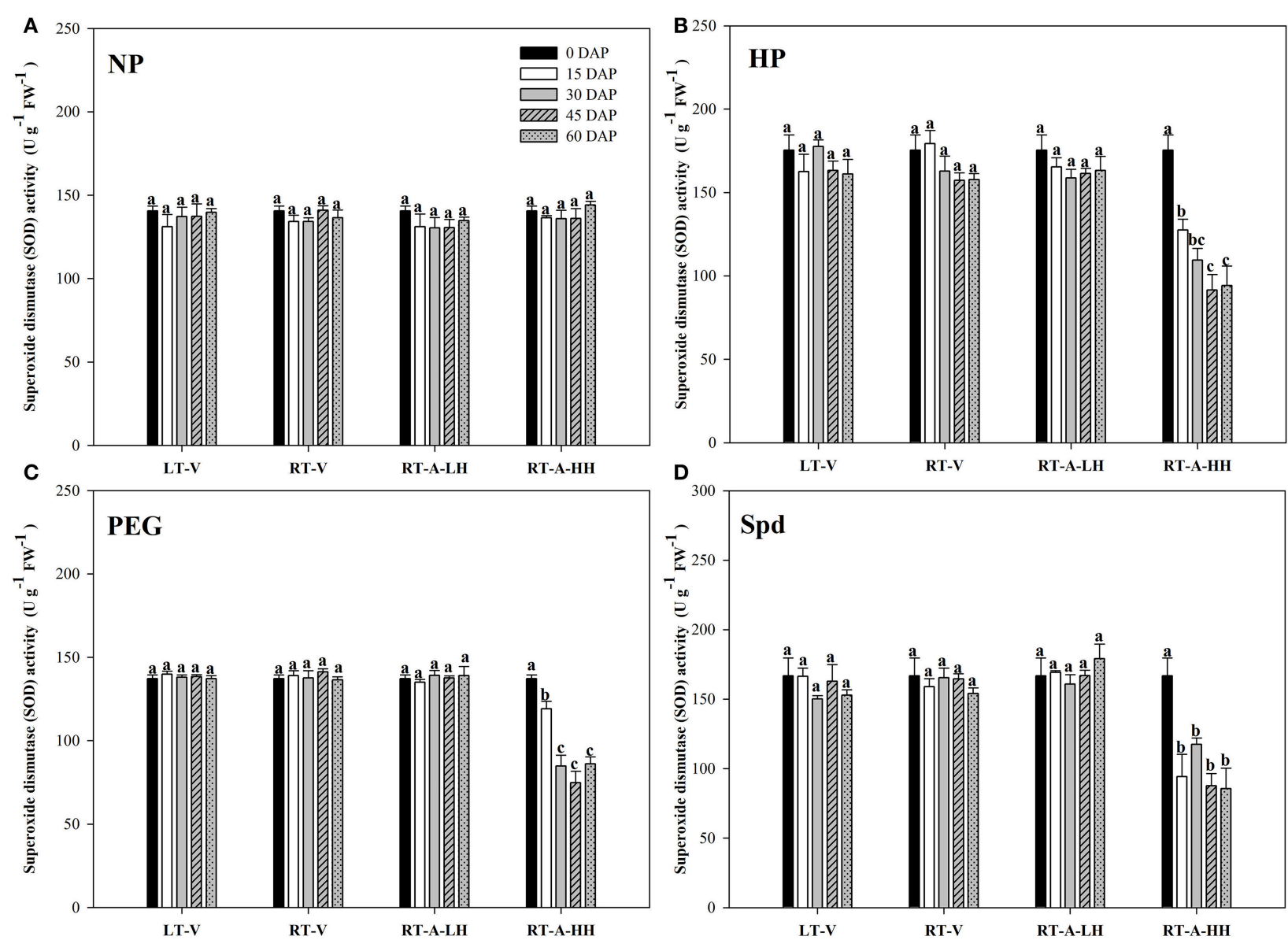

FIGURE 7 | Variations in superoxide dismutase (SOD) activity in primed and non-primed rice seeds under different storage conditions and storage durations. (A) Non-primed control, (B) Hydro-priming, (C) Osmopriming, (D) Spermidine priming. DAS, days after sowing; DAP, days after priming; NP, non-primed control; HP, hydro-priming; PEG, Osmopriming; Spd, spermidine priming; LT-V, the primed and non-primed seeds were stored under vacuum, low temperature condition; RT-V, the primed and non-primed seeds were stored under vacuum, room temperature condition; RT-A-LH, the primed and non-primed seeds were stored under room temperature, aerobic and low relative humidity condition; $\mathrm{RT}-\mathrm{A}-\mathrm{HH}$, the primed and non-primed seeds were stored under room temperature, aerobic and high relative humidity condition. Error bar above mean indicate stand error $(n=4)$. Different letters denote difference between storage durations of a storage condition at the $5 \%$ level according to LSD test.

condition during 2 years of storage. Ellis et al. (2008) concluded that the effect of oxygen on seed deterioration increased as seed moisture content decreased. However, such negative effect was not observed in present study, this is probably because that the 60 days of storage was too short to reach the threshold point of seed deterioration. Besides, the oxygen concentration in the storage condition might not reach the point to trigger series of physiological metabolisms that could deplete longevity of primed and unprimed rice seeds. Further studies to examine the role of oxygen in influencing the viability of primed rice seeds during storage are needed.

Compared with RT-A-LH, increasing RH (RT-A-HH) significantly decreased germination and seedling growth attributes of primed rice seeds, which suggested that storage of primed rice seeds at high $\mathrm{RH}$ was mainly responsible for deterioration of primed rice seeds in present study. These results were consistent with several researches that reported high $\mathrm{RH}$, high temperature reduced the seed longevity during storage
(Powell and Matthews, 1977; Suma et al., 2013). High RH would directly lead to an increase in seed moisture content, which is detrimical for the viability of seeds during storage (Abba and Lovato, 1999). High seed moisture content along with high temperature and ambient oxygen would trigger series of metabolic changes, such as the accumulation of the reactive oxygen species, loss of membrane integrity, increase in respiration and the consumption of storage reserves, and thus lead to seed deterioration (McDonald, 1999; Liu et al., 2016). In contrary with primed rice seeds, the longevity of non-primed rice seeds stored under RT-A-HH did not reduce, suggesting that that primed rice seeds are more sensitive to high $\mathrm{RH}$ and high temperature than non-primed seeds. Previously, Hacisalihoglu et al. (1999) have also observed that the germination potential and percentage of primed lettuce seeds was significantly decreased exhibited when stored under mild storage conditions ( 45 ? at $50 \%$ relative humidity). It is might because primed seeds are easier to suffer from oxidation or damage than non-primed 


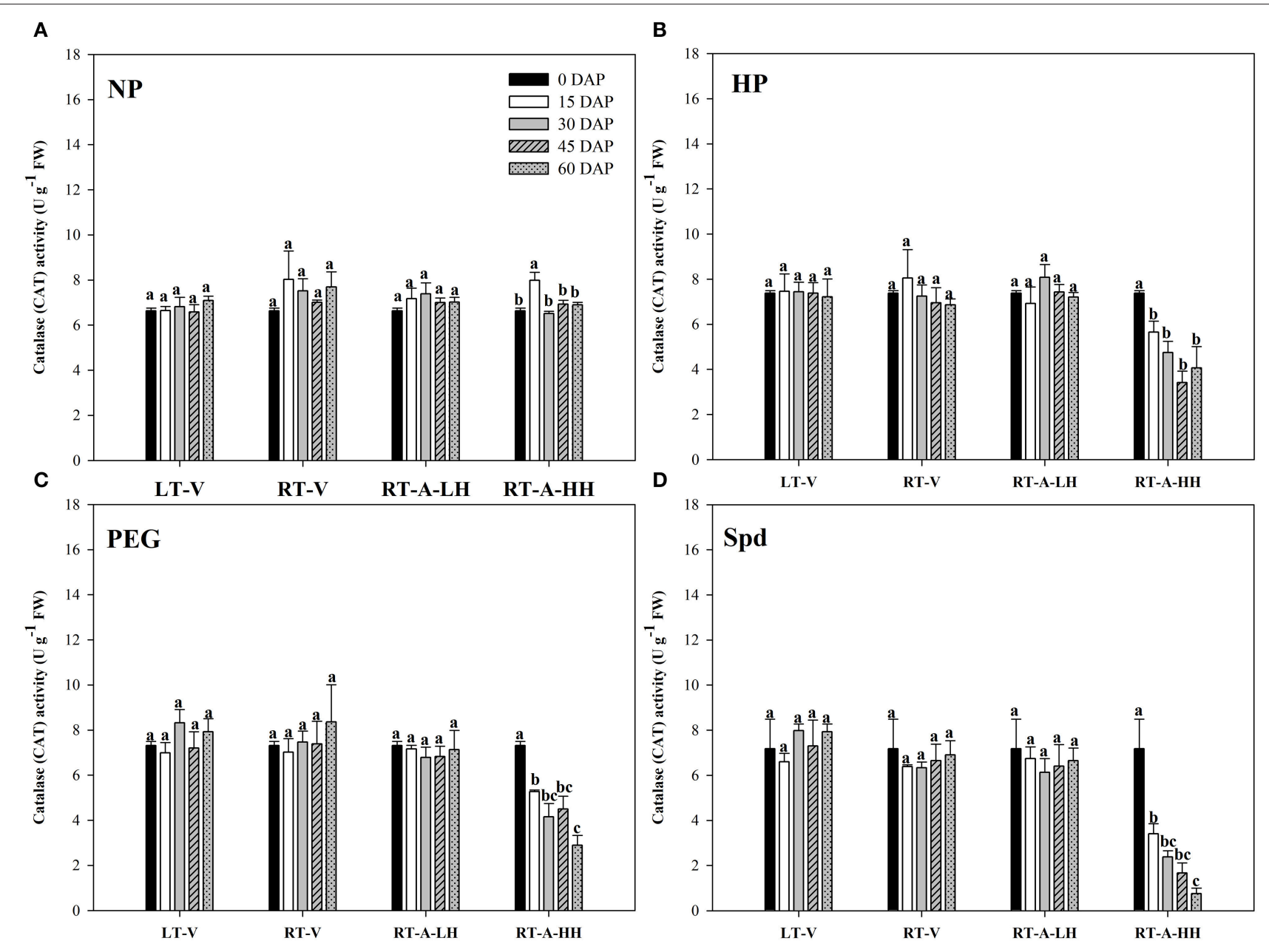

FIGURE 8 | Variations in catalase (CAT) activity in primed and non-primed rice seeds under different storage conditions and storage durations (A) Non-primed control, (B) Hydro-priming, (C) Osmopriming, (D) Spermidine priming. DAS, days after sowing; DAP, days after priming; NP, non-primed control; HP, hydro-priming; PEG, Osmopriming; Spd, spermidine priming; LT-V, the primed and non-primed seeds were stored under vacuum, low temperature condition; RT-V, the primed and non-primed seeds were stored under vacuum, room temperature condition; RT-A-LH, the primed and non-primed seeds were stored under room temperature, aerobic and low relative humidity condition; RT-A-HH, the primed and non-primed seeds were stored under room temperature, aerobic and high relative humidity condition. Error bar above mean indicate stand error $(n=4)$. Different letters denote difference between storage durations of a storage condition at the $5 \%$ level according to LSD test.

seeds during storage, which resulted in faster seed deterioration (Hussain et al., 2015). In summary, present study suggested that with low relative air humidity, the primed rice seeds could be aerobically stored at room temperature for 60 days, while increasing $\mathrm{RH}$ would drastically lose the viability of primed rice seeds.

In the present study, the reduction in starch metabolism and the consumption of stored reserves in the endosperms might be responsible for the viability loss of primed rice seeds stored under RT-A-HH. Starch metabolism is the major driving force for rice seed germination and could support plants to grow faster under various environment (Murata et al., 1968). Reduced starch metabolism in primed seedlings were strongly correlated with the decreased germination percentage and seedling growth attributes. The restriction of starch metabolism in primed rice seed during storage might be caused by the accumulation of reactive oxygen species. Storage of primed seeds under unfavorable condition would impair the antioxidative systems (Chang and Sung, 1998), lead to the damage of cell structures (Kaewnaree et al., 2011), break the metabolism balance and ultimately hampered the synthesize of associated amylase proteins. The consumption of starch reserves in the endosperms might be another reason for the reduced starch metabolism of primed rice seeds after storage. However, it has been suggested that even with the depletion of food reserves, seeds still have ample energy to support the germination process (Justice and Bass, 1978). The pre-consumption of starch reserves in primed seeds might result in a breakdown of food transport system (Harrington, 1960). Besides, Oxley (1948) suggested that exhaustion of an unnamed organic compound resulted in loss of seed viability during storage. However, the mechanisms associated with the deterioration of primed seeds 


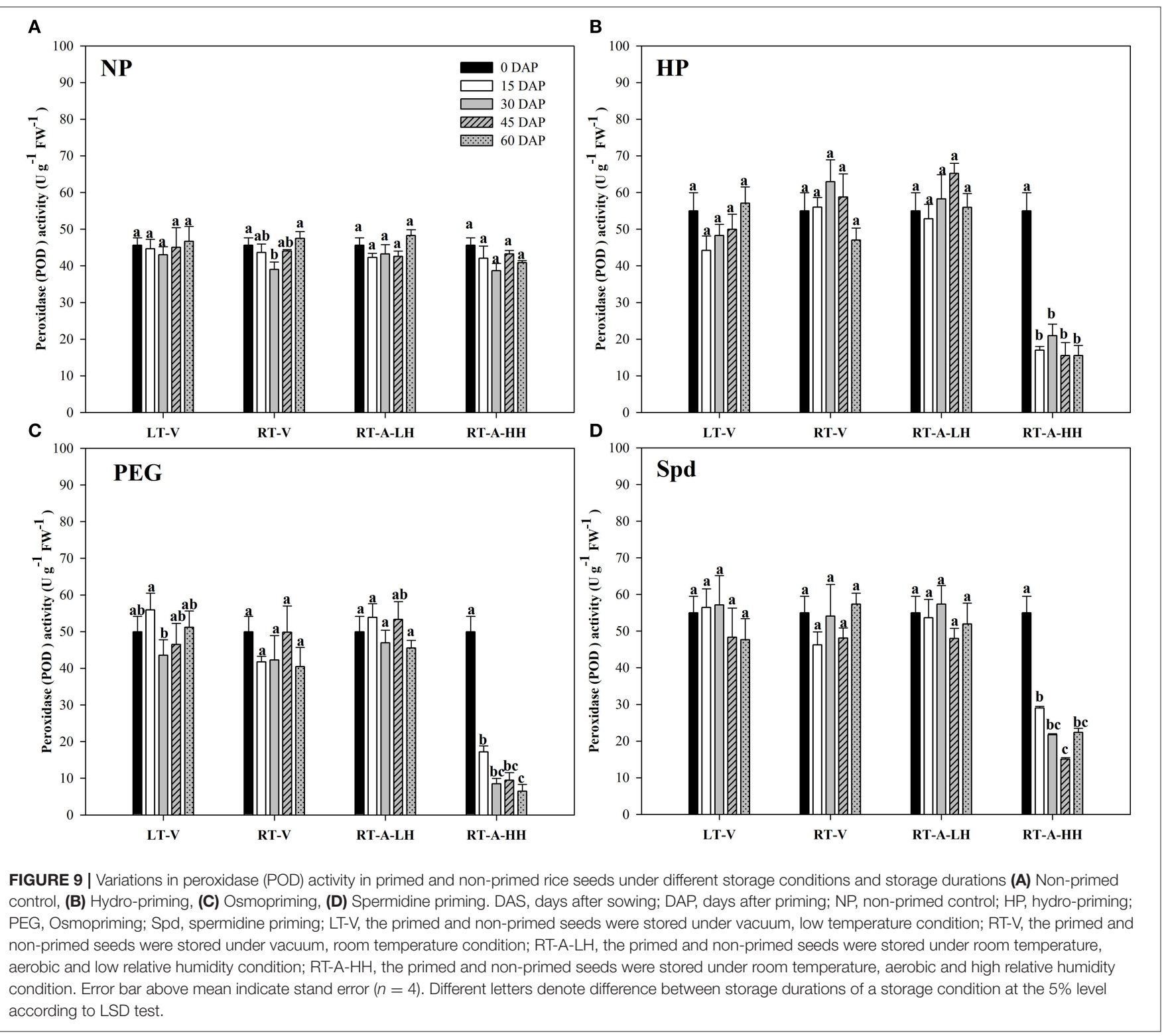

during storage are not fully understood and need to be studied further.

The deterioration of primed rice seeds stored under RTA-HH was closely related to the increased lipid peroxidation level (reflected by the MDA content) in the present study (Figure 6). This results were consistent with previous research showing that lipid peroxidation was one of the major causes of seed aging during storage (Maskri et al., 2003; Sung and Jeng, 2010; Veselovsky and Veselova, 2012). Our present study also indicated that the primed rice seeds were much easier to suffer from lipid peroxidation damage than non-primed rice seeds during storage (Figure 6). This might be because that priming treatments could activate several metabolic events in rice seeds, which accelerates the ROS accumulation and thus leads to the increased lipid peroxidation levels during storage. The decreased activity of POD, CAT and SOD were also responsible for the increased lipid peroxidation levels in primed rice seeds stored at RT-A-HH (Figures 7-9). The decreases of antioxidant enzymes activity severely hampered ROS scavenge and accelerated lipid peroxidation. In summary, our present study suggested that the increased lipid peroxidation levels and decreased antioxidant enzyme activities were associated with the deterioration of primed rice seeds stored at RT-A-HH. However, the regulation mechanisms associated with the ROS accumulation and scavenge in primed rice seeds under various storage conditions and durations need to be explored.

In addition to starch metabolism, antioxidant enzymes activity and lipid peroxidation, others have also been suggested to be associated with seed deterioration during storage. Petla et al. (2016) demonstrated the important role of PROTEIN L-ISOASPARTYL O-METHYLTRANSFERASE (PIMT) in regulating seed longevity, and suggested that PIMT repaired 
antioxidative enzymes and proteins which restrict lipid peroxidation and thus increased seed longevity (Petla et al., 2016). Yin et al. (2017) indicated that protein oxidation might be responsible for seed aging. Eisvand et al. (2010) reported that hormone priming could alleviate the damaging effect of seed aging. Kranner et al. (2011) suggested that DNA fragmentation and loss of RNA integrity were strongly linked with seed aging. In addition, the proteomic and transcriptomic analysis in primed and non-primed rice seeds under various different storage conditions and storage durations will be examined in our further work.

Almost similar responses of three priming treatments in present studies to varying seeds storage conditions and durations suggests the possibility for applicability of these findings to wide range of priming agents in rice crop. However, seed storage potential may still differ among different cultivars and species. Further studies should concentrate on screening and breeding cultivars with high storage potential.

\section{CONCLUSION}

Our study conclusively revealed that storage of primed seeds under high $\mathrm{RH}$ condition beyond 15 days is deteriorative for germination and growth of rice, and such damaging effects

\section{REFERENCES}

Abba, E. J., and Lovato, A. (1999). Effect of seed storage temperature and relative humidity on maize (Zea mays L.) seed viability and vigour. Seed Sci. Technol. 27, 101-114.

Association of Official Seed Analysis (1990). Rules for testing seeds. J. Seed Technol. $12,1-112$.

Beers, R. F., and Sizer, I. W. (1952). A spectrophotometric method for measuring the breakdown of hydroge n peroxide by catalase. J. Biol. Chem. 95, 133-140.

Bernfeld, P. (1955). Methods in Enzymology. New York, NY: Academic Press.

Calucci, L., Capocchi, A., Galleschi, L., Ghiringhelli, S., Pinzino, C., Saviozzi, F., et al. (2004). Antioxidants, free radicals, storage proteins, puroindolines, and proteolytic activities in bread wheat (Triticum aestivum) seeds during accelerated aging. J. Agr. Food Chem. 52, 4274-4281. doi: 10.1021/jf03 53741

Catusse, J., Meinhard, J., Job, C., Strub, J. M., Fischer, U., Pestsova, E., et al., (2011). Proteomics reveals potential biomarkers of seed vigor in sugar beet. Proteomics 11, 1569-1580. doi: 10.1002/pmic.201000586

Chance, B., and Maehly, A. C. (1995). Assay of catalase and peroxidase. Meth. Enzymol. 2, 764-775. doi: 10.1016/S0076-6879(55)02300-8

Chang, S. M., and Sung, J. M. (1998). Deteriorative changes in primed sweet corn seeds during storage. Seed Sci. Technol. 26, 613-626.

Chiu, K. Y., Chen, C. L., and Sung, J. M. (2003). Partial vacuum storage improves the longevity of primed sh-2 sweet corn seeds. Horti. Sci. 98, 99-111. doi: 10.1016/S0304-4238(02)00206-6

Demirkaya, M., Dietz, K. J., and Sivritepe, H. Ö. (2010). Changes in antioxidant enzymes during ageing of onion seeds. Not. Bot. Horti. Agrobo. 38, 49-52. doi: $10.15835 /$ nbha3814575

Dubois, M., Giles, K. A., Hamilton, J. J., Roberes, P. A., and Smith, F. (1956). Colorometric method for determination of sugars and related substances. Anal. Chem. 28, 350-356. doi: 10.1021/ac60111a017

Eisvand, H. R., Tavakkolafshari, R., Sharifzadeh, F., Arefi, H. M., and Hejazi, S. M. H. (2010). Effects of hormonal priming and drought stress on activity and isozyme profiles of antioxidant enzymes in deteriorated seed of tall wheatgrass (agropyron elongatum host). Seed Sci. Technol. 38, 280-297. doi: 10.15258/sst.2010.38.2.02 were related with reduced starch metabolism, consumption of starch reserves in rice endosperm, increased lipid peroxidation levels and decreased antioxidant enzyme activities. However, if primed seeds were stored at vacuum or low $\mathrm{RH}$ or low temperature conditions, there will be no negative effect on seed viability within 60 days of storage. These findings will have practical implications for the application and promotion of seed priming.

\section{AUTHOR CONTRIBUTIONS}

WW and LN: initiated and designed the research; WW and $\mathrm{AH}$ : performed the experiments, WW and LN: analyzed the data and wrote the manuscript, $\mathrm{SP}, \mathrm{JH}$, and $\mathrm{KC}$ revised and edited the manuscript and also provided advice on the experiments.

\section{FUNDING}

This work is supported by the National Natural Science Foundation of China (Project No. 31371571), the National High Technology Research and Development Program of China (863 Program) (Project No. 2014AA10A605), and the Fundamental Research Funds for the Central Universities (Project No. 2662017JC001).

Ellis, R. H., Hong, T. D., and Roberts, E. H. (2008). Seed moisture content, storage, viability and vigor. Seed Sci. Res. 1, 275-279. doi: 10.1017/S0960258500 001008

Feng, J., Zhao, Z., Liu, H., Wang, H., and Li, J. (2017). Effects of seed moisture content and storage condition on platycodon grandiflorum seed quality. Guizhou Agr. Sci. 45, 24-27. doi: 10.1100/2012/128105

Foyer, C. H., and Noctor, G. (2005). Oxidant and antioxidant signaling in plants: a re-evaluation of the concept of oxidative stress in a physiological context. Plant Cell Environ. 28, 1056-1071. doi: 10.1111/j.1365-3040.2005. 01327.x

Garcia, I. S., Souza, A., Barbedo, C. J., Dietrich, S. M., and Figueiredo, R. C. L. (2006). Changes in soluble carbohydrates during storage of Caesalpinia echinata LAM. (Brazilwood) seeds, an endangered leguminous tree from the Brazilian Atlantic Forest. Braz. J. Biol. 66, 739-745. doi: 10.1590/S1519-69842006000400018

Gill, S. S., and Tuteja, N. (2010). Reactive oxygen species and antioxidant machinery in abiotic stress tolerance in crop plants. Plant Physiol. Biochem. 48, 909-930. doi: 10.1016/j.plaphy.2010.08.016

Goyoagaa, C., Burbano, C., and Cuadrado, C. (2011). Content and distribution of protein, sugars and inositol phosphates during the germination and seedling growth of two cultivars of Vicia faba. J. Food Compo. Anal. 24, 391-397. doi: 10.1016/j.jfca.2010.11.002

Hacisalihoglu, G., Taylor, A. G., Paine, D. H., Hildebrand, M. B., and Khan, A. A. (1999). Embryo elongation and germination rates as sensitive indicators of lettuce seed quality: priming and aging studies. Hort. Sci. 34, 1240-1243.

Harrington, J. F. (1960). Drying, Storing and Packaging Seeds to Maintain Germination and Vigor. Short Course for Seedsman. Starkville, MS: Mississippi State University.

Hendry, G. A. F. (1993). Oxygen, free radical processes and seed longevity. Seed Sci. Res. 3, 141-153. doi: 10.1017/S0960258500001720

Heydecker, W., and Coolbear, P. (1977). Seed treatments for improved performance-survey and attempted prognosis. Nurs. Times 104, 20-21.

Hill, H. J., Cunningham, J. D., Bradford, K. J., and Taylor, A. G. (2007). Primed lettuce seeds exhibit increased sensitivity to moisture during aging. Hort. Sci. 42, 1436-1439. doi: 10.17660/ActaHortic.2008.782.14 
Hu, X., Tao, M., Lu, X., and Xin, P. (2006). Studies on the respiration and ethylene released amount of ultradried seed stored at different temperature. Seed 25, 13-16. doi: 10.16590/j.cnki.1001-4705.2006.02.039

Hussain, S., Khan, F., Hussain, H., and Nie, L. (2016a). Physiological and biochemical mechanisms of seed priming-induced chilling tolerance in rice cultivars. Front. Plant Sci. 7:116. doi: 10.3389/fpls.2016.00116

Hussain, S., Yin, H., Peng, S., Khan, F., Sameeullah, M., Hussain, H., et al. (2016b). Comparative transcriptional profiling of primed and non-primed rice seedlings under submergence stress. Front. Plant Sci. 7:1125. doi: 10.3389/fpls.2016.01125

Hussain, S., Zheng, M., Khan, F., Khaliq, A., Fahad, S., Peng, S., et al. (2015). Benefits of rice seed priming are offset permanently by prolonged storage and the storage conditions. Sci. Rep. 5:8101. doi: 10.1038/srep08101

Justice, O. L., and Bass, L. N. (1978)."Principles and practices of seed storage," in Agriculture Handbook, Vol. 506 (Washington, DC: USDA Printing Office), 25-198.

Kaewnaree, P., Vichitphan, S., Klanrit, P., Siri, B., and Vichitphan, K. (2011). Effect of accelerated aging process on seed quality and biochemical changes in sweet pepper (Capsicum annuum L.) seeds. Biotechnology 10, 175-182. doi: 10.3923/biotech.2011.175.182

Kaloyereas, S. A. (1955). A gas storage for preserving rough rice. Rice J. 58, 40-42.

Kranner, I., Chen, H., Pritchard, H. W., Pearce, S. R., and Birtić, S. (2011). Internucleosomal DNA fragmentation and loss of RNA integrity during seed ageing. Plant Growth Regul. 63, 63-72. doi: 10.1007/s10725-010-9512-7

Liu, J., Gui, J., Gao, W., Ma, J., and Wang, Q. (2016). Review of the physiological and biochemical reactions and molecular mechanisms of seed aging. Acta Ecol. Sinica. 36, 4997-5006. doi: 10.5846/stxb201502040289

Maskri, A. Y., Khan, M. M., Khan, I. A., and Habsi, K. (2003). Effect of accelerated ageing on viability, vigor (RGR), lipid peroxidation and leakage in carrot (Daucus Carota L.) seeds. Int. J. Agric. Biol. 5, 580-584. Available online at: http://www.fspublishers.org/published_papers/7582_..pdf

McDonald, M. B. (1999). Seed deterioration: physiology, repair and assessment. Seed Sci. Tech. 27, 177-237.

Mira, S., Estrelles, E., and Gonzálezbenito, M. E. (2015). Effect of water content and temperature on seed longevity of seven brassicaceae species after 5 years of storage. Plant Biol. 17, 153-162. doi: 10.1111/plb.12183

Murata, T., Akazawa, T., and Fukuchi, S. (1968). Enzymic mechanism of starch breakdown in germinating rice seeds i. an analytical study. Plant Physiol. 43, 1899-1905. doi: 10.1104/pp.43.12.1899

Oxley, T. A. (1948). Scientific Principles of Grain Storage. Liverpool: North. Pub. Co.

Pallwall, S., Baskin, C. C., and Delouche, J. C. (1991). Scanning electron microscopy of high quality and low quality sorghum seeds. J. Seed Technol. 15, 42-57.

Petla, B. P., Kamble, N. U., Kumar, M., Verma, P., Ghosh, S., Singh, A., et al. (2016). Rice protein l-isoaspartyl methyltransferase isoforms differentially accumulate during seed maturation to restrict deleterious isoasp and reactive oxygen species accumulation and are implicated in seed vigor and longevity. New Phytol. 211, 627-645. doi: 10.1111/nph.13923

Powell, A. A., and Matthews, S. (1977). Deteriorative changes in pea seeds (Pisum sativum L.) stored in humid or dry conditions. J. Exp. Bot. 35, 277-284.

Rajjou, L., and Debeaujon, I. (2008). Seed longevity: survival and maintenance of high germination ability of dry seeds. C. R. Biol. 331, 796-805. doi: 10.1016/j.crvi.2008.07.021
Rajjou, L., Lovigny, Y., Groot, S. P. C., Belghazi, M., Job, C., and Job, D. (2008). Proteome-wide characterization of seed aging in Arabidopsis: a comparison between artificial and natural aging protocols. Plant Physiol. 148, 620-641. doi: 10.1104/pp.108.123141

Schwember, A. R., and Bradford, K. J. (2011). Oxygen interacts with priming, moisture content and temperature to affect the longevity of lettuce and onion seeds. Seed Sci. Res. 21, 175-185. doi: 10.1017/S09602585110 00080

Suma, A., Sreenivasan, K., Singh, A. K., and Radhamani, J. (2013). Role of relative humidity in processing and storage of seeds and assessment of variability in storage behaviour in Brassica spp. and Eruca sativa. Sci. World J. 11:504141. doi: $10.1155 / 2013 / 504141$

Sung, J. M., and Jeng, T. L. (2010). Lipid peroxidation and peroxide-scavenging enzymes associated with accelerated aging of peanut seed. Physiol. Plant. 91, 51-55. doi: 10.1111/j.1399-3054.1994.tb00658.x

Veselovsky, V. A., and Veselova, T. V. (2012). Lipid peroxidation, carbohydrate hydrolysis, and amadori-maillard reaction at early stages of dry seed aging. Russ. J. Plant Physiol. 59, 811-817. doi: 10.1134/S1021443712030181

Wang, W., Chen, Q., Hussain, S., Mei, J., Dong, H., Peng, S., et al., (2016). Pre-sowing seed treatments in direct-seeded early rice: consequences for emergence, seedling growth and associated metabolic events under chilling stress. Sci. Rep. 6:19637. doi: 10.1038/srep19637

Wilson, D. O., and McDonald, M. B. (1986). The lipid peroxidation model of seed ageing. Seed Sci. Technol. 14, 269-300.

Xu, H., Wei, Y., Zhu, Y., Lian, L., Xie, H., Cai, Q., et al. (2015). Antisense suppression of Lox3 gene expression in rice endosperm enhances seed longevity. Plant Biotechnol. J. 13, 526-539. doi: 10.1111/pbi.12277

Yeh, Y. M., Chiu, K. Y., Chen, C. L., and Sung, J. M. (2005). Partial vacuum extends the longevity of primed bitter gourd seeds by enhancing their anti-oxidative activities during storage. Sci. Hort. 104, 101-112. doi: 10.1016/j.scienta.2004.08.006

Yin, G., Xin, X., Fu, S., An, M., Wu, S., Chen, X., et al. (2017). Proteomic and carbonylation profile analysis at the critical node of seed ageing in Oryza sativa. Sci. Rep. 7:40611. doi: 10.1038/srep40611

Zheng, M., Hussain, S., Tao, Y., Jiang, Q., Peng, S., Huang, J., et al. (2016). Seed priming in dry seeded rice: consequences for emergence, seedling growth and associated metabolic events under drought stress. Plant Growth Regul. 78, 167-178. doi: 10.1007/s10725-015-0083-5

Zhu, C., and Chen, J. (2007). Changes in soluble sugar and antioxidant enzymes in peanut seeds during ultra dry storage and after accelerated aging. Seed Sci. Technol. 35, 387-401. doi: 10.15258/sst.2007.35.2.14

Conflict of Interest Statement: The authors declare that the research was conducted in the absence of any commercial or financial relationships that could be construed as a potential conflict of interest.

Copyright (c) 2018 Wang, He, Peng, Huang, Cui and Nie. This is an open-access article distributed under the terms of the Creative Commons Attribution License (CC $B Y)$. The use, distribution or reproduction in other forums is permitted, provided the original author(s) and the copyright owner are credited and that the original publication in this journal is cited, in accordance with accepted academic practice. No use, distribution or reproduction is permitted which does not comply with these terms. 